\title{
Market Reaction to Bank Liquidity Regulation
}

Journal of Financial and Quantitative Analysis (forthcoming)

Brunella Bruno ${ }^{a}$ Enrico Onali ${ }^{b}$, and Klaus Schaeck ${ }^{c^{*}}$

JEL Classification: $\quad G 21, G 28$

Keywords: $\quad$ liquidity regulation; market reaction; event study, Basel III

* Corresponding author.

a Department of Finance, Università Bocconi. E-mail: brunella.bruno@ unibocconi.it, Phone: + 39 (0)25836

5954

b Aston Business School, Aston University. E-mail: e.onali@aston.ac.uk, Phone: +44 (0)121 2043060

c Lancaster University Management School, Lancaster University. E-mail: k.schaeck@lancaster.ac.uk,

Phone: + $44(0) 1524593980$

\section{Acknowledgements}

We thank an anonymous referee, Paul Malatesta (the editor), Elena Carletti, Giuliano Iannotta, Piotr Danisewicz, Rafael Repullo, Andrea Resti, and Kasper Roszbach for comments on previous drafts. 


\title{
Market Reaction to Bank Liquidity
}

\section{Regulation}

\begin{abstract}
We measure market reactions to announcements concerning liquidity regulation, a key innovation in the Basel framework. Our initial results show that liquidity regulation attracts negative abnormal returns. However, the price responses are less pronounced when coinciding announcements concerning capital regulation are backed out, suggesting that markets do not consider liquidity regulation to be binding. Bank- and country-specific characteristics also matter. Liquid balance sheets and high charter values increase abnormal returns while smaller long-term funding mismatches reduce abnormal returns. Banks located in countries with large government debt and tight interbank conditions or with prior domestic liquidity regulation display lower abnormal returns.
\end{abstract}

JEL Classification: $\quad G 21, G 28$

Keywords: $\quad$ liquidity regulation; market reaction; event study, Basel III 


\section{Market Reaction to Bank Liquidity Regulation}

\section{Introduction}

We present the first empirical analysis of how stock markets respond to the new global standards of bank liquidity regulation which are gradually adopted between 2015 and 2018 . Unlike capital regulation, which has been a cornerstone of the regulatory framework for years, regulating bank liquidity was typically not a major concern prior to the recent crisis in most countries. The regulatory package (known as Basel III) that the Basel Committee on Banking Supervision (BCBS) developed in response to the recent financial crisis ${ }^{1}$ constitutes a fundamental change in that respect. For the first time, the BCBS introduces global standards for bank liquidity to improve liquidity risk management and banks' ability to withstand liquidity shocks (Calomiris, Heider, and Hoerova (2015)). Policy makers view these new standards as a major improvement in regulation after the recent crisis, as the following quote illustrates:

[The Basel III Framework is] a landmark achievement that will help protect financial stability and promote sustainable economic growth. The [...] global liquidity framework will significantly reduce the probability and severity of banking crises in the future

\footnotetext{
During the crisis, several banks faced substantial liquidity outflows and shortages owing to overreliance on volatile funding sources, improper asset-liability management, and off-balance-sheet positions which gave rise to liquidity risk (Strahan (2012)). Consequently, banks hoarded liquidity (Acharya and Merrouche (2013)), and reduced liquidity provision to other banks and to the real sector (Cornett, McNutt, Strahan, and Tehranian
} (2011)). 
Nout Wellink Chairman of the BCBS and President of the Netherlands Bank ${ }^{2}$

The new rules address different aspects of liquidity risk. The liquidity coverage ratio (LCR) aims to ensure that banks have high quality liquid assets available to accommodate short-term cash outflows. The net stable funding ratio (NSFR) requires a minimum volume of stable funding sources given a bank's asset structure to mitigate the risk of funding mismatches over a one year time horizon. These two ratios aim to achieve different objectives and they are, at least from a theoretical perspective, equally important for financial stability. An empirical question that we seek to answer in the paper is whether the market perceives the LCR as more important than the NSFR, or vice versa.

By requiring banks to switch to higher quality and more liquid assets, and towards more stable funding sources, the new standards are likely to affect banks' operations, in particular the structure of the balance sheet in terms of maturity structure and asset and funding choices. Therefore, complying with these rules has potential to affect bank profitability and valuation. Industry representatives expressed disquiet about the costs arising from the new rules which would reduce profits (Institute of International Finance (IIF) (2012)). The final version of Basel III, released after a five year period of intensive discussions and lobbying, entailed several amendments to the original proposal and a weakening of the initial guidelines.

To examine how market participants react to liquidity regulation, we use event study methodology and exploit seven official announcements by the BCBS regarding the introduction of global liquidity standards. We turn to this methodology because the new regulation is gradually implemented over several years from 2015 onwards and an examination of the long-term impact of the LCR and the NSFR on bank profitability is

\footnotetext{
${ }^{2}$ See BIS press release, Dec. 16, 2010 (http://www.bis.org/press/p101216.htm).
} 
infeasible due to the lack of historical information for the two ratios and the impossibility to compute them with the current level of disclosure in bank balance sheets. Therefore, only an event study approach and the combination of market and accounting data can be used to examine how markets expect bank profits to be affected.

We study European banks because their funding metrics compared unfavorably during and after the crisis with international peers, making them less prepared than U.S. and Japanese banks to meet the requirements in Basel III (European Banking Authority (EBA) (2012)). Moreover, the sovereign debt crisis amplified between 2010 and 2012 the funding problems in Europe where banks are subject to different national liquidity regimes, making convergence a desirable, yet challenging, objective to level the playing field. Finally, our cross-country comparison that focuses on large listed banks that display bank- and country-specific heterogeneities allows examining how banks headquartered in similar yet different banking systems respond to the new rules.

Our empirical strategy proceeds in three steps. First, we examine cumulative abnormal returns (CARs), and cumulative market-adjusted returns (CMARs) over 3-day event windows to estimate aggregate and average market reactions to seven announcements by the BCBS relating to proposals, amendments, and revisions of rules concerning bank liquidity regulation for the period Feb. 2008-Jan. 2013. Second, we disentangle stock price reactions that also refer to confounding events such as announcements concerning capital regulation from those that exclusively address liquidity regulation. To this end, we calculate CARs and CMARs over event dates that only relate to statements regarding liquidity regulation. Third, we analyze whether banks respond heterogeneously. We correlate the cross-sectional variation in CARs and CMARs with bank-specific and country-specific characteristics. These tests 
illustrate how CARs and CMARs increase or decrease as an effect of the pre-existing liquidity conditions, funding mismatch, charter values, and country-specific characteristics that affect the two-way feedback between the sovereign's creditworthiness and refinancing conditions in the interbank market.

Several arguments suggest that bank stock prices may respond to liquidity regulation. Even if the regulation is not implemented yet, bank stock prices can reflect the market perception regarding the possible consequences of liquidity regulation.

One view is that regulation serves the public interest to promote welfare at the expense of the regulated industry (Needham (1983)). Clearly, achieving and maintaining safe and sound banking, and mitigating systemic risk serves the public interest. Indeed, these arguments are put forward by the policy community for regulating bank liquidity. On the other hand is the capture theory. Stigler (1971) and Peltzman (1976) posit that regulation is desired by the regulated industry to reap benefits at the expense of opposing parties. Consistent with this view, lobbying by the banking industry against this regulation resulted in amendments that watered down the initial proposal and led to an eventually less restrictive regime.

Analyzing the effects of changes in regulation using event studies has received much attention in the economics and banking literature (Schwert (1981), Dann and James (1982), James (1983), Allen and Wilhelm (1988), Slovin, Sushka, and Bendeck (1990), Wagster (1996), Bayazitova and Shivadasani (2012), Norden, Roosenboom, and Wang (2013), and Horváth and Huizinga (2015)). However, event study methodology is not without challenges. First, the public debates about regulation during and after the crisis made investors anticipate tighter regulation, suggesting that markets may have expected regulatory changes prior to the announcements of the BCBS. We deal with this problem using a 3-day event window centred 
on the announcement day. Moreover, we test for anticipation effects using placebo events we pretend to occur prior to the actual events. Second, liquidity regulation is only one component of the regulatory framework. Some announcements relating to liquidity regulation coincide with announcements on capital regulation or other aspects of Basel III. Establishing a causal effect of market reactions to liquidity regulation requires identifying such confounding news. A key contribution of our study is to disentangle the effects of announcements that also contain information concerning other components of Basel III (specifically, capital adequacy regulation) from the effects that are solely attributable to liquidity regulation. We refer to those tests as the Liquidity only bucket. These tests shed light on the question of whether market participants view liquidity regulation as binding and help establish their value relevance. Last, share prices may also respond to corporate events, such as changes in corporate governance or dividend cuts. We also show tests that omit bank-specific events that coincide with the BCBS announcements.

Our initial set of tests points towards negative stock price reactions to the introduction of liquidity regulation. The aggregate effect on shareholders of European banks based on the CARs for all seven events is equivalent to an average decrease in market capitalization between 269 and 354 million Euros, depending on the proxy for the market portfolio (MSCI Europe and MSCI World, respectively). These figures represent a decline in market capitalization of $-5.27 \%$, and $-6.95 \%$, respectively. However, our inferences are more nuanced when we separate out the announcements relating to capital regulation and other components of Basel III. Tests based on the Liquidity only bucket highlight that the average stock price reaction is either only marginally significant or insignificant. These analyses suggest that markets do not consider these new rules to be binding. Therefore, their value 
relevance is more limited than our initial results suggest. Our interpretation is plausible because the standards were not implemented yet. Precisely, while a smooth and gradual process of implementation was finalised for the LCR, the NSFR will only become a binding requirement by 2018 and observers anticipate further modifications to be made (Santos and Elliot (2012)).

Further tests illustrate that bank-specific variables explain the cross-sectional variation in stock price reactions to test the motivation behind the LCR and the NFSR. Banks with a greater LIQUID_ASSETS_RATIO (defined as the ratio of liquid assets to customer and shortterm funding) which serves as a proxy for the LCR, display less negative CARs and CMARs. This is in line with the idea that banks with more liquid balance sheets react better to the new rules. Our proxy for the NSFR, the CORE_FUNDING_RATIO, enters our tests with a negative sign, suggesting more negative CARs and CMARs for higher levels of CORE_FUNDING_RATIO. As explained in detail below, this result reflects that the CORE_FUNDING_RATIO is largely driven by Tier 1 capital, an expensive source of funds. ${ }^{3}$ Country-specific factors also matter: banks from countries with more government debt experience more negative CARs and CMARs, and the negative wealth effects are also more pronounced if banks are headquartered in countries that already had national provisions for liquidity risk in place prior to the new rules.

Our research complements the evolving literature on Basel III. These studies address the effect of new regulation on economic growth and the cost of lending (Banerjee and Mio (2015), Duijm and Wierts (2016)). Our work is also related to the broader literature on

\footnotetext{
Including off-balance sheet items (such as guarantees and other contingent liabilities) and excluding liquid assets in the denominator of the CORE_FUNDING_RATIO does not alter our results.
} 
banking regulation and its impact on banking sector development, performance and stability (Barth, Caprio, and Levine (2004)), and the effect of regulation compliance on soundness (Demirgüç-Kunt, Detragiache, and Tressel (2008)). Our work differs from those studies by focusing specifically on the reaction by market participants to the introduction of a novel component of the Basel III framework: the regulation of liquidity risk.

We proceed as follows. Section II describes the institutional background, and Section III introduces testable predictions. Section IV describes the data and Section V the methodology. The results are presented in Section VI. Section VII concludes.

\section{Institutional Background}

On Feb. 21, 2008, the BCBS published a document entitled Liquidity Risk Management and Supervisory Challenges as an initial response to the 2007-2009 crisis. This document summarises the findings of a review by the committee on national supervisory regimes and banks' practices to manage liquidity in times of difficulty. In light of banks' poor liquidity management and the diversity of national liquidity regimes, the document illustrates possible actions to strengthen liquidity risk management and coordinate supervision.

On June 17, 2008, the BCBS proposed 17 Principles for Sound Liquidity Risk Management and Supervision, a review of a previous document on liquidity management introducing criteria for funding structure and liquidity standards. The Committee issued the final version of Principles on Sept. 25, 2008 after receiving comments. Next, the BCBS released the International Framework for Liquidity Risk Measurement, Standards and Monitoring on Dec. 17, 2009. This framework aims to elevate the resilience of international banks to liquidity shocks and harmonize international liquidity risk supervision. It also introduces global standards for liquidity risk supervision to achieve two objectives: 
i) To strengthen banks' ability to withstand liquidity shocks over a short-term period, the BCBS developed the LCR. The standard requires banks to hold sufficient high quality liquid assets (HQLA), such as cash or government bonds, to meet a severe cash outflow for 30 days. The standard was introduced in 2015.

ii) To promote long-term resilience and reduce maturity mismatch, the BCBS proposed the NSFR. It incentivizes the use of stable funding sources by limiting short-term wholesale funding. Precisely, it requires banks to hold equity and liability financing expected to be reliable sources of funds over a one-year time horizon. The amount of stable funds required is conditional on liquidity characteristics of assets on and off the balance-sheet. The standard will be introduced in 2018 .

Appendix A presents a detailed description of the two requirements. ${ }^{4}$ The initial reaction to the announcements about regulating liquidity was negative. ${ }^{5}$ Next, the BCBS decided to gradually introduce the standards to avoid detrimental effects on lending. ${ }^{6}$ Consequently, the initial proposal was amended, and in two cases (Events \#5 and \#7) these adjustments resulted in a loosening of the liquidity requirements relative to previous announcements. We briefly discuss the key features of these events.

A first set of amendments was set out in the Annex to the BCBS press release on July 26,

4 Both measures are included in the Dec. 2010 Basel III Agreement (Event \#6). From this point in time, supervisors monitored the ratios. However, there was a great deal of objection by the industry and the BCBS indicated the likelihood of further refinements in the formulas prior to the start of the mandatory period. Further, data gathered during the observation period may lead to further changes (Santos and Elliott (2012)).

5 See, for example, Financial Times, Dec. 17, 2009 (“Basel was Faulty”).

6 See the press release "Consultative proposals to strengthen the resilience of the banking sector announced by the Basel Committee", Dec. 17, 2009 downloadable at http://www.bis.org/press/p091217.htm. 
2010 (Event \#5). The objective of the revisions was "to achieve a calibration and definition that penalises imprudent liquidity profiles, while minimising system level distortions” (p. 5). In particular, the LCR was relaxed by widening the range of qualifying liquid assets, and the NSFR was modified to favor retail over wholesale banking, mainly by loosening requirements for customer deposits and residential mortgages.

In response to these objections and to take into account problems in the Eurozone, the BCBS modified the short-term liquidity standard (Event \#7). The Committee announced the introduction of Basel III: The Liquidity Coverage Ratio and Liquidity Risk Monitoring Tools on Jan. 7, 2013. The main changes to the LCR entailed a wider set of HQLA and more lenient assumptions for the calculation of net cash outflows. The document also clarified the possibility for banks to fall below the minimum LCR requirement during periods of stress.

Moreover, the BCBS decided to delay the full implementation of the standards. ${ }^{7}$

We summarize the seven key events examined in this research in the following timeline.

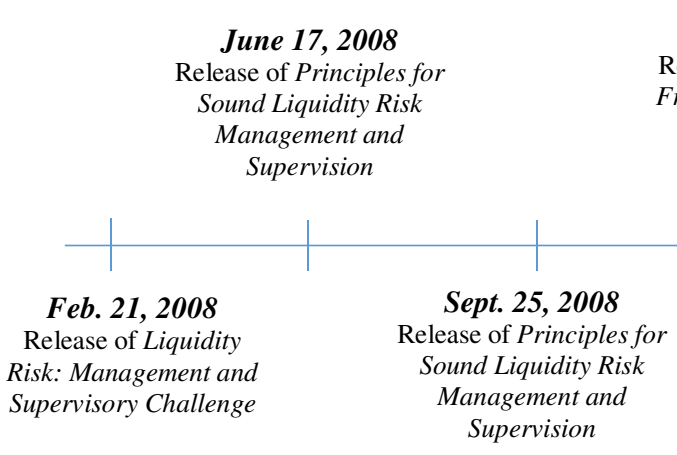

Dec. 17, 2009

Release of International Framework for Liquidity Risk Measurement Standards and Monitoring
Dec. 16, 2010

Release of Basel III: International Framework for Liquidity Risk Measurement, Standards and Monitoring

Table 1 assesses the impact of each event on the probability of stricter liquidity rules after each event and the corresponding stock price effect. Appendix B describes the BCBS events

7 The LCR was introduced on Jan. 1, 2015 with a minimum requirement of 60\%. It will rise in annual steps of $10 \%$ to reach $100 \%$ on Jan. 1, 2019. 
in greater detail.

\section{[TABLE 1: ASSESSMENT OF IMPACT OF EACH EVENT]}

\section{Testable Predictions}

We develop predictions for how bank stock prices respond to liquidity regulation. Next, we discuss how bank- and country-level features amplify or mitigate the stock price returns.

\section{A. Hypotheses on Market Reactions to Liquidity Regulation}

Several arguments suggest that liquidity regulation attracts negative stock price reactions. Introducing quantitative liquidity requirements aims to correct banks' suboptimal liquidity choices to restore optimal liquidity. A priori, it appears plausible to expect that such regulation interferes with banks' business operations which are geared towards profit maximization, and shareholders are likely to respond negatively.

The negative view on holding liquidity is driven by the fact that liquidity facilitates managerial moral hazard (Jensen (1986)). Moreover, liquidity holdings are considered to be costly for several reasons. Myers and Rajan (1998) highlight the 'dark side' of liquidity. By holding more liquid assets, firms are less likely to commit to a specific investment strategy that protects creditors because more liquid firms have a higher value in liquidation. A manager will therefore use the more liquid assets to alter the implicit property rights she has to maximize her own benefit. Indeed, Glaeser and Shleifer (2001) and Ratnovski (2009) propose that quantity regulation is costly: a precise definition of what constitutes a liquid asset in the context of bank liquidity regulation is difficult. While assets that are unconditionally eligible for central bank repo operations may have guaranteed liquidity, they are restricted to a subset of high-quality government bonds. Thus, these assets are expensive to hold. Other 
assets such as highly-rated corporate bonds may be liquid during tranquil times but their liquidity may dry up during market stress. Ex ante, it is therefore difficult to judge which assets constitute liquid assets that serve as a building block for liquidity regulation.

Moreover, mandating banks to hold liquid assets gives rise to opportunity costs because it interferes with asset choices in a similar vein as do minimum reserve requirements. Slovin et al. (1990) show that increases in unremunerated reserve requirements reduce shareholder wealth. Such requirements are an excise tax on banking activities that lower future cash flows. While liquidity regulation does not compromise banks' asset choices and profitability to the same extent as do reserve requirements, the direction of the effect is similar. In absence of such regulations, banks may deploy the funds to finance loans that attract higher yields than government bonds. Liquidity regulation, similar to reserve requirements, is therefore likely to reduce income and, concomitantly, bank profits.

We also acknowledge an alternative hypothesis that predicts positive shareholder wealth effects. The point of departure for this view is that the new rules reduce systemic risk and limit contagion (Cifuentes, Ferrucci, and Shin (2005)). By forestalling contagious failures and improving soundness, liquidity regulation increases the probability of survival of banks, and simultaneously increases charter values. Banerjee and Mio (2015) illustrate the contagionreducing effect of liquidity regulation. They show that tighter liquidity regulation reduces interconnectedness of the banking sector. Finally, share prices may respond positively due to convergence benefits towards a global standard of liquidity regulation. Such convergence benefits arise from a common standard of regulating liquidity. This is beneficial because Beck, Todorov, and Wagner (2013) demonstrate in the context of resolving cross-border bank distress that national regulators may have biased incentives to intervene into such institutions. 


\section{B. What Explains the Cross-Sectional Variation in Stock Price Returns?}

Beyond understanding how markets respond to liquidity regulation, we investigate whether bank- and country-specific characteristics amplify or mitigate the shareholder wealth effects. Economic intuition and prior work on liquidity risk suggest that bank-specific characteristics warrant further investigation. This analysis is also relevant from a policy perspective to enable regulators to gauge how banks are likely to respond to the new rules.

We focus on characteristics that capture the motivation behind liquidity regulation: funding mismatches and funding mix. Ideally, any such analysis pays attention to the LCR and the NSFR, and these ratios' components. However, the data required to compute both ratios are not yet disclosed in the balance sheets. To overcome this challenge, we rely on plausible approximations of the LCR and the NFSR using data from BankScope. Subsequently, we also discuss the role of charter values because holding liquidity increases the likelihood of preserving the bank as a going concern and preserves the value of the charter.

\section{Long-Run Funding Mix: Liability Composition}

The mix of funding sources and the extent to which banks are exposed to funding mismatch, reflected in the composition of the liability side of the balance sheet, is likely to increase or decrease stock price reactions. The rules for liquidity regulation tighten the funding conditions by placing restrictions on what constitutes long-term stable funding sources. In particular, poorly capitalized banks as well as those relying on wholesale shortterm funds may be forced to issue equity, and move towards long-term borrowing to comply with the NSFR. 
We argue that tightening funding for poorly capitalized banks may attract greater negative stock price reactions as these banks are more likely to suffer from an increase in funding costs. In contrast, institutions whose balance sheet characteristics signal that assets are largely supported by long-term stable funds are less pressed to adjust the asset-liability mix relative to banks far off the required standards. We therefore anticipate the negative shareholder wealth effects to be smaller in magnitude for banks with a relatively limited funding mismatch. This will be reflected in a higher coverage of assets financed by long-term funds (e.g., equity). This hypothesis matches the intuition behind the NSFR.

Hypothesis 1. A higher funding mismatch has a negative impact on the price reaction to bank liquidity regulation.

We test this hypothesis using the CORE_FUNDING_RATIO (the sum of Tier 1 capital plus hybrid debt and customer deposits divided by total assets) as a proxy for the NSFR. Because this ratio is inversely related to funding mismatch, Hypothesis 1 is consistent with a positive coefficient.

\section{Liquidity of Bank Balance Sheets: Asset Composition}

Banks whose balance sheet characteristics suggest that the volume of liquid assets can absorb large and sudden cash outflows are in a better position to accommodate liquidity requirements, and are less pressed to adjust the asset and liability mix. ${ }^{8}$ Thus, we expect the

\footnotetext{
Ideally, an empirical proxy for the NFSR also considers asset quality in terms of risk-weights, ratings, and issuers. However, in a cross-country study like ours such a granular level of data is not available.
} 
adverse shareholder wealth effects that we anticipate to be less pronounced for banks with more liquid assets. Such a hypothesis directly tests the intuition behind the LCR.

Hypothesis 2. More liquid balance sheets will have a positive impact on the share price reaction.

To test this hypothesis, we use the ratio of liquid assets to customer and short-term funding (LIQUID_ASSETS_RATIO) as a proxy for the LCR. ${ }^{9}$

\section{Charter Values}

Recent work by Ratnovski (2009) establishes a link between banks' liquidity choices and charter values. The basic premise is that maintaining liquidity insures the charter value. In a two-bank model, he shows that banks reduce liquidity if charter values are low or when banks expect shocks that will reduce charter value. These outcomes are due to inter-bank strategic complementarities with respect to liquidity choices. ${ }^{10}$ When banks expect their competitors to

9 Customer funding consists of current accounts, savings accounts, and time deposits from customers. Note that meeting the standards of the LCR may also require banks to move towards more high quality assets. In other words, banks that have ex ante poor asset quality may have to adjust the asset side to comply with the LCR. We therefore examine the effect of a key indicator of asset quality, the ratio of non-performing loans to total assets, on CARs and CMARs. However, the $t$-statistic on this variable remains indistinguishable from zero and our other inferences are unaffected. The results are available from the authors.

10 Ratnovski (2009) focuses on crises. He shows that banks herd in equilibrium. This results in low levels of liquidity when they expect other banks to display suboptimal levels of liquidity. This is driven by banks' anticipation of rents that arise from bailouts that distort liquidity choices. The choice trades off the preservation 
be illiquid (e.g., during crises or when other banks suffer liquidity shocks) and bailouts are likely, a bank will choose high levels of illiquidity. In contrast, when other banks are liquid or when other banks are likely to survive liquidity shocks, banks have incentives to be liquid. While the two-bank model takes a banking-system perspective, Ratnovski's (2009) work also translates into two bank-level predictions. First, individual banks' liquidity levels should correlate positively with charter values. ${ }^{11}$ This prediction reflects that banks insure charter values by holding liquidity. Second, since liquidity regulation reduces the probability of bailouts and the associated rents, banks with higher charter values are likely to attract better price reactions than banks with lower charter values.

Hypothesis 3. Higher charter values have positive effects on price reactions to liquidity regulation.

Our empirical strategy relies on two alternative measures of charter values: the Market to-book ratio (MARKET_TO_BOOK_RATIO), and the ratio of customer deposits to total assets (CUS_DEP_TO_TOT_ASSETS, a proxy for core deposits). These proxies find motivation in Keeley (1990) and Goyal (2005).

of charter values versus bailout rents. The intuition is that liquid banks have a higher probability to survive and realize long-term returns. In contrast, illiquid banks are likely to fail, and this attracts bailout rents.

11 In unreported tests, we run auxiliary regressions of the proxies for charter values (MARKET_TO_BOOK_RATIO and CUS_DEP_TO_TOT_ASSETS) on the LIQUID_ASSETS_RATIO. We find positive and significant associations, supporting Ratnovski's (2009) intuition in his model. The results are available from the authors. 


\section{Two-Way Feedback Loops between Banking Sector Conditions and Sovereign Debt}

We also investigate country-specific factors to understand how they affect the market reaction to announcements related to the new liquidity regulation.

The interbank market conditions between core Eurozone members and countries located at the periphery such as Greece, Ireland, Italy, Portugal, and Spain (henceforth referred to as GIIPS) differ considerably. Figure 1 shows these countries on a map, illustrated in dark grey.

\section{[FIGURE 1]}

These characteristics may play a role for the way equity markets respond to liquidity regulation. Acharya, Drechsler, and Schnabl (2014) suggest that this divergence of interbank market conditions is largely due to sovereign problems in these peripheral countries, reflecting two-way feedback effects from sovereign credit risk to the domestic banking industry and vice versa. Le Leslé (2012) also attributes differences in bank funding conditions between core and peripheral countries to concerns about the fragility of the economies in stressed Eurozone countries. To illustrate, deposit rates in interbank markets at short maturities below one year for core countries in the Euro area declined in line with the Euribor spread in the aftermath of European Central Bank's actions in 2011 but deposit rates for banks located at the periphery remained around 150 basis points higher at the end of 2012. Given that tighter liquidity regulation implies higher cost of capital, we expect tighter interbank funding conditions in countries that experienced sovereign debt problems to trigger greater negative stock price reactions. Therefore, for countries whose banks are on average net lenders in the interbank market, we anticipate larger stock price reactions to liquidity regulation than for countries whose banks are, on average, net borrowers (and therefore have tighter funding conditions). 
Hypothesis 4. Higher average interbank ratios on the country level have positive effects on the price reaction to liquidity regulation.

Related to the previous argument is the link between a country's fiscal position, government debt, and domestic interbank market conditions. Budget deficits signal that governments spend more than they earn per fiscal year. Unless such deficits are exclusively financed by minting funds, they result in increases in national debt which further undermines the sovereign's creditworthiness, aggravating the adverse feedback effects between sovereign risk and the banks' refinancing conditions. Importantly, the recent bailouts in the form of recapitalizations are closely associated with increases in government debt. For instance, Lane (2012) highlights that Ireland and Portugal witnessed increases in debt to gross domestic product (GDP) ratios during the crisis, and Acharya et al. (2014) show that increases in financial sector distress correlate positively with increases in the public debt to GDP ratios. Via the two-way feedback loop, the higher sovereign credit risk triggers further increases in the refinancing costs of the banking sector. For these reasons, we expect worse price reactions for banks domiciled in countries with high debt to GDP ratios, and in particular for those in the periphery countries, as they were most affected by the Eurozone crisis.

Hypothesis 5. Greater government indebtedness has a negative effect on the price reaction to liquidity regulation. Being domiciled in a GIIPS country has a negative impact on the price reaction to liquidity regulation. 
Finally, we hypothesize that banks headquartered in the Eurozone may display more negative stock price reactions than banks located elsewhere. Figure 2 highlights in dark grey the countries that are not members of the Eurozone.

\section{[FIGURE 2]}

This differential effect is reflective of concerns about contagion in the Eurozone that may ultimately also affect the refinancing conditions in the banking sector and liquidity risk. Such concerns were repeatedly raised in the media, and also find support in academic work. For instance, the Financial Times stresses on Feb. 24, 2010 that debt levels in several Eurozone countries raise fears of ratings downgrades for other member countries, and the Wall Street Journal reports on Nov. 26, 2010 on contagion risk arising from Greece and Ireland for Belgium. ${ }^{12}$ Recent work by Lucas, Schwaab, and Zhang (2014) investigates default probabilities in nine Eurozone member countries conditional on a default of Greece. They show that Ireland and Portugal would be most affected by a Greek default with conditional probabilities of failure of approximately $30 \%$. Other countries (e.g., Austria, Belgium, Germany, Spain, France, and Italy) display conditional default probabilities below $20 \%$.

Hypothesis 6 . Location in a Eurozone country negatively affects the price reaction to liquidity regulation. $^{13}$

12 See Oakley (2010) Sovereigns: Debt Levels Raise Fears of Further Downgrades, Financial Times, Feb. 24, 2010, and Robinson (2010) Belgian Debt and Contagion. The Wall Street Journal, Nov. 26, 2010.

${ }^{13}$ An additional reason for expecting a negative impact of being domiciled in the Eurozone is the fact that large Eurozone banks may be supervised directly by the Single Supervisory Mechanism (SSM) led by the European Central Bank. If the SSM is considered by market participants to be a tougher supervisor that national 
We rely on several measures to capture the role of interbank conditions, sovereign debt, the government's fiscal position, and bank location. We use BankScope to compute the position of a bank in the interbank market by scaling money lent to other banks by the money borrowed from other banks. A higher interbank ratio suggests that a bank is a net placer in the interbank market. Next, we calculate the average of this variable, called INTERBANK_RATIO, for each country and each year. To gauge how the fiscal position affects stock prices, we retrieve the debt-to-GDP ratio (DEBT_TO_GDP_RATIO) from World Bank Development Indicators. The effect of Eurozone membership is captured with a dummy, EUROZONE, that takes on the value of 1 if a country uses the Euro currency $(0$ otherwise). We use a dummy variable, GIIPS, to identify banks located in any of the five GIIPS countries that experienced sovereign debt problems.

\section{Pre-Existing Domestic Liquidity Regulation}

Several countries had some form of domestic liquidity regulation in place prior to the announcements by the Basel Committee.

To establish which countries had guidelines for liquidity risk in place, we first screen the survey by the World Bank on Banking Regulation and Supervision, using the waves for 2003, 2007, and 2012; Cihak, Demirgüç-Kunt, Martinez Peria, and Mohseni-Cheraghlou (2012)). Using several waves ensures obtaining information about guidelines on liquidity risk prior to

supervisors this may also explain why new liquidity regulations have a relatively large negative impact on stock prices of banks from the Eurozone. Section IV.A highlights that many of the banks in our sample are indeed subject to the SSM. 
the crisis, and we can also trace the evolution of these provisions during the sample period. We focus on that section in the database which contains details about guidelines for liquidity risk. We then verify this information by cross-checking the details with information from the websites of the countries' central banks and the Bank for International Settlements (BIS). ${ }^{14}$ Denmark, Germany, the Netherlands, Switzerland, and the United Kingdom had provisions in place that aim to bolster banks' liquidity holdings. Figure 3 highlights these countries in dark grey.

[FIGURE 3]

The Danish rules stipulate that banks are required to have adequate liquidity, and are based on ratios that resemble the spirit of the LCR. Similar provisions exist for Germany. Since 2003, the Dutch guidelines also contain quantitative liquidity requirements that resemble the new proposals. Switzerland introduced quantitative liquidity requirements in 1988, and the United Kingdom also had minimum liquidity requirements in place with the objective to avoid maturity mismatches. We expect shareholders of institutions headquartered in these countries to respond more negatively to the new rules because they are potentially better able than shareholders elsewhere to gauge the effect of new regulation for bank profitability.

However, the effect of prior legislation may also go in the opposite direction. For banks that are already subject to national liquidity requirements any new liquidity requirement as part of Basel III may not lead to an observable reduction in bank profitability. Hence, it is also possible that shareholders of institutions headquartered in these countries will respond less

\footnotetext{
14 See, for instance, de Haan and van den End (2012), Banerjee and Mio (2015), and http://www.bundesbank.de/Navigation/EN/Tasks/Banking_supervision/Liquidity/liquidity.html.
} 
negatively to the new liquidity regulation. We therefore offer two alternative hypotheses on the effect of pre-existing domestic liquidity regulation:

Hypothesis 7A. Being headquartered in a country with pre-existing domestic regulations on liquidity has a negative impact on the price reaction to liquidity regulation.

Hypothesis $7 B$. Being headquartered in a country with pre-existing domestic regulations on liquidity has a positive impact on the price reaction to liquidity regulation.

Our tests use a dummy, LIQUIDITY_REGULATION, that takes on the value of 1 in instances when a country has pre-existing domestic liquidity regulation in place $(0$ otherwise). ${ }^{15}$ A negative coefficient on this dummy variable would indicate that Hypothesis 7A is applicable, while a positive coefficient would support Hypothesis 7B. If the two effects offset each other, the coefficient may be insignificant.

\section{Data, Representativeness, and Choice of Event Dates}

We now discuss our sample. While our empirical work only considers listed banks, liquidity regulation extends to all banks, irrespective of their listing. Therefore, we also

15 In the United Kingdom, the Financial Services Authority (FSA) imposed capital requirements on individual banks which were bank-specific but not publicly announced (Aiyar, Calomiris, Hooley, Korniyenko, and Wieladek (2014)). In unreported tests, we remove all U.K. banks from the sample to avoid any confounding effects from these bank-specific capital requirements which may have coincided with the announcements about liquidity regulation. Our findings remain virtually unchanged; these tests are available from the authors. 
discuss sample representativeness. Subsequently, we elaborate on the choice of our event dates.

\section{A. Data and Representativeness}

The starting point for the sample selection is the population of commercial banks and bank holding companies (BHCs) in the European Union (EU) and Switzerland, as reported in BankScope. BankScope is our source for the bank-specific variables used below to establish heterogeneous responses to liquidity regulation. We include Switzerland because of the vast size of its banking system and the linkages of Swiss banks with banks in the EU.

BankScope contains data for 142 banks and BHCs in Europe listed on a stock exchange. We filter out banks without deposits to ensure that the sample banks engage in financial intermediation. This screen reduces the sample by 14 banks for which BankScope records zero deposits. We also omit seven observations for five banks due to negative common equity, resulting in a final sample of 128 banks and BHCs. Appendix C presents more details. For these banks, we retrieve daily closing prices from DataStream for the period Feb. 21, 2007 to Jan. 7, 2013 for our event study.

Table 2 provides an overview of the sample composition. Panel A shows the number of sample banks and their aggregate market share by country to illustrate the representativeness because these 128 banks are only a subset of the European banking system. This discussion is important because liquidity regulation applies to all banks in the EU and Switzerland but very often only the largest banks are publicly listed. The sample banks account on average for 57\% of total banking system assets in the domestic banking systems, $57 \%$ of total loans, and for $39 \%$ of total liabilities. In Sweden, the sample banks represent over $91 \%$ of total banking system assets, over $90 \%$ of total loans, and over $77 \%$ of total liabilities. The relevance of 
these banks is also reflected in the fact that many of them are systemically important. Of the 78 sample banks located in the Eurozone, 40 fall under the Single Supervisory Mechanism. Panel B of Table 2 reports means and standard deviations for the bank-and country-specific variables used to explain the CARs and CMARs below. Apart from the values on the DEBT_TO_GDP_RATIO, the data refer to the period 2007-2012 to allow for the delay in the release of information via the annual reports. Close scrutiny of the standard deviations highlights considerable within-country heterogeneities for the bank-specific variables, where the standard deviations range from 0.02 in Malta for the CORE_FUNDING_RATIO in the minimum to 1.13 for the Swiss LIQUID_ASSETS_RATIO in the maximum. These heterogeneities are most pronounced for MARKET_TO_BOOK_RATIO, whose standard deviations are between 0.29 (Finland) and 2.27 (Sweden).

[TABLE 2: SAMPLE COMPOSITION, REPRESENTATIVENESS, DESCRIPTIVE STATISTICS]

\section{B. Event Dates}

Our event dates refer exclusively to official announcements by the BCBS that result in proposed or actual changes of liquidity regulation. This choice is a restrictive, yet plausible, criterion. Any other news and debates regarding the introduction of liquidity regulation are based on and influenced by the debates within the BCBS and its representatives.

The selection of event dates proceeds as follows. First, we use public information from the BIS website to determine all events and dates leading up to the Basel III framework. We consider all events in the sections of the BIS website referred to as: i) the Global Regulatory Framework for Capital and Liquidity, comprising the entire spectrum of measures introduced by the BCBS through Basel II, Basel 2.5, and Basel III accords; and ii) the Basel Committee's 
Response to the Financial Crisis, which focuses initiatives undertaken by the BCBS since the 2007-2009 crisis. $^{16}$

Second, we refine the list of events by considering only those related to Basel III, and drop initiatives referred to Basel II, and Basel 2.5 accords. As discussed above, to establish the wealth effects that are causally attributable to liquidity regulation we need to be aware that Basel III also encompasses other types of regulation. We therefore only select events with proposed or actual changes in liquidity regulation, and drop events focusing on capital requirements only. However, some rules that address liquidity regulation have been released at the same time as measures on capital requirements. We consider these dates only when the event involves a major change in liquidity regulation. To ultimately understand the extent to which market reactions are driven by announcements other than those related to liquidity and disentangle market reactions to liquidity regulation from confounding announcements relating to other aspects of Basel II, we also calculate CARs and CMARs over the event dates which entail exclusively initiatives on liquidity (i.e., Events \#1, \#2, \#3, and \#7, i.e., the Liquidity only bucket).

Third, we conduct a media search to ascertain that the events we focus on indeed convey significant information to the market. This media search helps rule out anticipation effects, a key concern for event study analysis. To this end, we carefully search major international media outlets (Financial Times, Wall Street Journal, Wall Street Journal Europe, International Herald Tribune) via LEXIS/NEXIS for a period up to one week after each of the seven event dates. This exercise suggests substantial international media coverage in the correspondence

\footnotetext{
${ }^{16}$ See http://www.bis.org/bcbs/basel3/compilation.htm and http://www.bis.org/bcbs/fincriscomp.htm, respectively.
} 
to all events included in our empirical tests. ${ }^{17}$ To allay concerns about anticipation effects, we extend this news search to a week, i.e., 5 trading days, prior to the event date.

Finally, we record the day of the week on which the BCBS publicly released its statement. For our calculation of abnormal returns across event dates, we verify that each announcement has been released prior to the closing times of European stock exchanges. ${ }^{18}$ This condition ensures that the new information is available to all stock exchanges.

\section{Econometric Methodology}

Modeling market reactions to the announcements of the BCBS presents econometric challenges. The literature lacks consensus on the choice of the estimation method for abnormal returns. Moreover, Brown and Warner (1980) stress that short event-window models based on estimation of the security's beta (such as the market model or the CAPM) do not lead to significantly more precise estimates for the abnormal returns. For these reasons, we estimate both abnormal returns (AR) and market-adjusted returns (MAR) for the event window $(-1,1)$, followed by calculation of the CARs and CMARs for each event (Focarelli, Pozzolo, and Casolaro (2008)).

17 We employ a variety of keyword searches to assess the international press coverage of the Basel Committee's initiatives included in our analysis. In particular, we use the following keywords: bank liquidity, liquidity proposals, Basel Committee, BIS, Bank for International Settlements, liquidity risk, Basel 3, Basel III, bank supervisors, bank supervision, and liquidity management.

18 When the hour of the press release is unavailable we screen the international press to check whether any European bank stock reaction is reported, on the date of the event, in response to the Basel Committee's announcement. 
We estimate the AR using the market model extended to include day-of-the-week dummies (Kaplanski and Levy (2010)):

$$
\mathrm{AR}_{i, t}=R_{i, t}-\left(\alpha_{i}+\beta_{i} R_{m, t}+\sum_{d=2}^{5} \lambda_{d} D_{d}\right)
$$

where

$D_{d}=1 \quad$ if $d=2$ for Tuesdays, $d=3$ for Wednesdays, $d=4$ for Thursdays, and $d=5$ for Fridays, and $D_{d}=0$ otherwise.

Consistent with prior work (e.g., Armour, Mayer, and Polo (forthcoming)), we employ an estimation window of 260 trading days $(-261,-2)$ for the market model. Because we consider a long sample period, using different estimation windows for each event instead of only one estimation window for all events allows for potential parameter instability over time. We also adjust for first-order autocorrelation in the error term of the market model regression using the Prais-Winsten method (Allen and Wilhelm (1988)).

We compute the market-adjusted return (MAR) as the difference between the log return of the security $\left(R_{i, t}\right)$ and the $\log$ return of the proxy for the market portfolio $\left(R_{m, t}\right)$

$$
\mathrm{MAR}_{i, t}=R_{i, t}-R_{m, t},
$$

The literature highlights that the MAR is free of bias resulting from significant events in the estimation period, which undermines estimation of the beta (Fuller, Netter, and Stegemoller (2002)). Since our sample period covers part of the 2007-2009 financial crisis and the Eurozone crisis, it is likely that significant events affected estimation of the beta.

We then compute the corresponding CAR and CMAR for the 3-day event window (-1, 1). Focusing on short event windows is particularly useful for the purpose of this study 
because this restrictive criterion reduces the impact of potentially confounding events. Their influence typically increases as the event window widens.

$$
\begin{aligned}
\mathrm{CAR}_{i, t} & =\sum_{t=t 1}^{t 2} \mathrm{AR}_{i, t}, \\
\mathrm{CMAR}_{i, t} & =\sum_{t=t 1}^{t 2} \mathrm{MAR}_{i, t},
\end{aligned}
$$

For our regressions we rely on 3-day event windows, where $t_{1}$ is the trading day before the event and $t_{2}$ the trading day after the event.

We adopt the MSCI World and the MSCI Europe as proxies for the market portfolio. These proxies, especially the first one, are less subject to bias than national indices because of potential effects of liquidity regulation on the stock prices of non-financial firms of a country. The first step of our analysis focuses on the market-wide reaction to liquidity regulation using equal-weighted and market-weighted portfolios of the bank stocks in our sample. We compute the aggregate effect of the regulation by considering the average CARs and CMARs over all seven events, followed by tests for the four Liquidity only events that back out the effects of other aspects of Basel III.

To correctly gauge the market reaction to stricter liquidity rules even though Events \#5 and \#7 (see Table 1) are associated with loosening of the initial proposals, we follow the standard approach in the literature pioneered by Armstrong, Barth, Jagolinzer, and Riedl (2010), and multiply the corresponding CAR or CMAR by minus one for these two events. For example, a positive price reaction for Events \#5 and \#7 suggests that bank shareholders benefit from looser liquidity requirements, and therefore it would not make sense to sum the raw CARs or CMARs for these events to the CARs and CMARs for the other five events. 
After multiplying the CARs and CMARs for these events by minus one, the sum of CARs and CMARs for all events measures the market reaction to stricter liquidity rules appropriately. Because we have only seven and four events for the total effects and the Liquidity only events, calculating the significance of the CARs and CMARs based on the assumption of Normality may lead to unreliable $t$-statistics. For this reason, we rely on bootstrap simulations to evaluate the significance of the cumulative effect of all seven events and the effect of the four Liquidity only events, similar to Armstrong et al. (2010).

The bootstrap simulations are performed as follows: we exclude days which fall in the 3day window for the seven events to consider only non-event trading days. Next, we randomly choose seven (or four, for the results pertaining to the Liquidity only bucket) non-overlapping placebo events for the period Feb. 1, 2008 to Feb. 28, 2013. This step is repeated 800 times. Finally, we compute the sum of the CAR and CMAR over all seven (and four) events for each of the 800 samples of placebo events. These steps ensure that the simulated data represent the distribution of CAR and CMAR under the null hypothesis because they are estimated for nonevent trading days (for which announcements related to liquidity regulation did not occur). The $p$-values are computed on the basis of the number of cases for which the CAR or CMAR is larger or smaller than the estimated value based on 2-tail tests.

For the second stage of our analysis, we run regressions of the CARs and CMARs on both a vector of bank-level $\left(\mathbf{B}_{\mathbf{i}, \mathbf{t}}\right)$ and a vector of country-level $\left(\mathbf{C}_{\mathbf{i}, \mathbf{t}}\right)$ characteristics: ${ }^{19}$

19 Investigating the cross-sectional determinants of CARs using such a two-stage approach is common in banking. Focarelli et al. (2008) employ a similar methodology to examine how the share of the arranger of syndicated loans (as well as characteristics related to the syndicate structure, the credit facility and the borrower) affect the share price reaction of the borrower. 


$$
\mathrm{CAR}_{i, t}=a+b \mathbf{C}_{\mathbf{i}, \mathbf{t}}+c \mathbf{B}_{\mathbf{i}, \mathbf{t}}+\varepsilon_{i, t},
$$

$$
\mathrm{CMAR}_{i, t}=d+e \mathbf{C}_{\mathbf{i}, \mathbf{t}}+f \mathbf{B}_{\mathbf{i}, \mathbf{t}}+\eta_{i, t}
$$

The vector $\mathbf{B}_{\mathbf{i}, \mathbf{t}}$ consists of the CORE_FUNDING_RATIO, LIQUID_ASSETS_RATIO, CUS_DEP_TO_TOT_ASSETS, and MARKET_TO_BOOK_RATIO. The vector $\mathbf{C}_{\mathbf{i}, \mathbf{t}}$ comprises DEBT_TO_GDP_RATIO, the dummy variables EUROZONE, GIIPS, and LIQUIDITY_REGULATION, and the INTERBANK_RATIO. ${ }^{20}$ We winsorize all bank-level explanatory variables at the 1st and 99th percentile, as well as the CARs and CMARs (Armour et al. (forthcoming)). Because some of the variables are time-invariant, such as GIIPS or EUROZONE, we estimate all the regressions using a random effects model with heteroskedasticity-robust standard errors clustered on the country-level.

\section{Results}

We first provide a visual inspection of the behavior of CARs and CMARs around the event date, and then present the empirical analysis for the market reactions. Subsequently, we show tests that relate bank-specific and country-specific characteristics to the CARs and CMARs.

\footnotetext{
20 All coefficients in the tables on the cross-sectional regressions should be read as follows: A negative coefficient signals that an increase in variable $\mathbf{B}_{\mathbf{i}, \mathrm{t}}$ generates a decrease in the CAR/CMAR (i.e., if the CAR/CMAR is negative, this amplifies the reduction). A positive coefficient signals that an increase in variable $\mathbf{B}_{\mathbf{i}, \mathbf{t}}$ generates an increase in the CAR/CMAR (i.e., if the CAR/CMAR is negative, this mitigates the reduction and potentially leads to a positive CAR/CMAR).
} 


\section{A. Market Reaction to Bank Liquidity Regulation: Aggregate and Individual Effects}

Graphs A-D in Figure 4 illustrate the behavior of equal-weighted and market-weighted CARs and CMARs around a 3-day event window centred on the announcement date (represented with a vertical solid bold line). The solid line represents CARs (Graphs A and B) or CMARs (Graphs C and D) estimated using the MSCI World as a proxy for the market portfolio, while the dashed line represents CARs (Graphs A and B) or CMARs (Graphs C and D) estimated using the MSCI Europe as a proxy for the market portfolio. Graphs A and C use a market-weighted portfolio of banks, while Graphs B and D use an equal-weighted portfolio of the bank stocks in our sample. The four graphs consistently indicate declines in CARs and CMARs around the announcement dates. A slight decline on the day prior to the announcements suggests that there may have been information leakages, this supports our choice to focus on the event window $(-1,1)$.

[FIGURE 4]

\section{Aggregate Effects}

Table 3 presents our first set of analyses. We compute the total and the average effect for all seven events. Table 3 reproduces the findings for both equal-weighted and marketweighted portfolios. We also present bootstrapped $p$-values for the average CAR or CMAR, based on 800 bootstrap simulations for the period Feb. 1, 2008-Feb. 28, 2013, as discussed above. Importantly, we also present the results for the Liquidity only bucket based on randomly selected trading days. The latter setup is the most rigorous way of establishing the causal effects of liquidity regulation on bank stock prices. 
Panel A of Table 3 uses the MSCI World as a proxy for the market index, and Panel B relies on the MSCI Europe. Panel A points towards negative wealth effects arising from the announcements. The $t$-statistics for the total effect are statistically significant in three cases out of four. The average $\operatorname{CAR}(-1,1)$ and $\operatorname{CMAR}(-1,1)$ ranges between -0.0095 and -0.0221 , and the price reaction is stronger for the market-weighted portfolios (with a CAR of -0.0188 and a CMAR -0.0221$)$ than for the equal-weighted portfolio (-0.0099 and -0.0095$)$, suggesting that bigger banks react more negatively to the regulation than smaller banks. Panel B shows that using the MSCI Europe yields very similar inferences. The $t$-statistics are significant in three out of four cases for the total effect. Likewise, the average CAR and CMAR considering all seven events is larger in magnitude for the market-weighted portfolio $(-0.0143$ and -0.0159$)$ than for the equal-weighted portfolio $(-0.0075$ and -0.0033$)$.

The economic magnitude of these aggregate effects appears sizeable. Considering the sum of the $\operatorname{CAR}(-1,1)$ for all seven events for the market-weighted portfolios, the overall loss in market capitalization amounts to a staggering 354 million Euros in Panel A (equivalent to a reduction in market capitalization for all listed banks in Europe by -6.95\%), and 269 million Euros in Panel B (a decline in market capitalization by $-5.27 \%$ ).

\section{Individual Effects}

Clearly, we focus on the aggregate effect of announcements concerning liquidity regulation. For completeness, however, we also briefly discuss the market reactions to the seven individual announcements. These tests are useful to establish if the market responses are consistent with the hypothesised direction of the effects in terms of tightening or loosening of the initial proposals concerning liquidity regulation. To preserve space, these tests are 
relegated to Table A.1 in our Internet Appendix (available at www.jfqa.org) which reports the CARs and CMARs.

Three observations stand out. First, several of the individual announcements attract negative market reactions. This is consistent with both the visual inspection of the data and the aggregate effect documented so far. Second, consistent with our expectations, Events \#5 and \#7 result in positive stock price reactions due to the loosening of the initial proposals (consistent with Table 3, we multiply these CARs and CMARs by minus one in Table A.1). Third, the largest price reaction is for Event \#7 which is the final and definitive announcement for the LCR which again relaxed previously proposed liquidity rules. The magnitude of the market reaction suggests that the extent of the relaxation surprised the market more than the previous announcements.

\section{Liquidity only Bucket}

However, these tests still leave open the possibility that confounding announcements from the BCBS on capital regulation or any other component of Basel III drive the results. Concluding that liquidity regulation causally drives reductions in market capitalization would be inappropriate. Indeed, our inspection of the tests based on the Liquidity only bucket highlights that the $t$-statistics are only weakly significant or insignificant when we back out confounding effects. In line with the decline of statistical significance, the economic magnitude of the adverse price movements is less pronounced. The loss related to the events 1, 2, 3, and 7 amounts to 206 million Euros in Panel A, and 154 million Euros in Panel B.

Which factors are behind these weaker inferences? First, the findings for the Liquidity only bucket are likely to due to a loss of power of the tests when only four events are considered. Second, the events we exclude from the Liquidity only bucket are important for 
market participants in the sense that these announcements received extensive media coverage because they cover not only liquidity regulation but also other characteristics of Basel III. ${ }^{21}$ The decline both in terms of statistical significance and in terms of economic magnitude is therefore not surprising. Liquidity regulation is only one component of the revised Basel framework. The findings for the Liquidity only bucket are therefore bound to be weaker. Third, and most importantly, the revisions and the lobbying by the industry to mitigate the effects of tight liquidity regulation suggests that markets did not consider the new rules to be binding at the time of the announcement. The successful lobbying fuelled expectations about further modifications (Santos and Elliott (2012)). For instance, the LCR has been amended twice since its initial proposal, to eventually allow additional, less liquid instruments to be considered as high quality liquid assets (Fullenkamp and Rochon (2016)). This is consequently reflected in limited effects for bank valuation.

[TABLE 3: AGGREGATE STOCK MARKET REACTION]

\section{Placebo Tests}

Table 3 also contains tests based on placebo events that assume the events considering the CARs and CMARs occur five trading days prior to the each one of the actual events. These tests help understand whether the results are driven by a downward trend in returns of bank stocks relative to the market in the days surrounding the events. Moreover, these analyses also allow ruling out anticipation effects that may have occurred prior to the event windows.

\footnotetext{
A representative news item in the Financial Times on July 27, 2010 reads "Global banking regulators reached a breakthrough agreement yesterday to tighten capital requirements and impose new worldwide liquidity and leverage standards, but softened some of their proposals and delayed others until at least 2018.”
} 
Irrespective of the choice of the proxy for the market portfolio, all placebo events in Panel A and Panel B of Table 3 remain insignificant at the 5\% level. These tests suggest the absence of anticipation effects and alleviate the concern that the significance of the results for the actual events is due to short-run trends in the CARs and CMARs.

\section{B. Country- and Bank-Specific Characteristics and Stock Price Reactions}

Table 4 shows how bank- and country-specific variables correlate with the stock price reactions. We again present results with both the MSCI World (Panel A), and the MSCI Europe (Panel B) index as a proxy for the market portfolio.

\section{[TABLE 4: BANK- AND COUNTRY-LEVEL CHARACTERISTICS]}

Importantly, these tests demonstrate that bank-specific variables explain much of the variation in CARs and CMARs. Our analysis that focuses on the intuition behind the LCR using the LIQUID_ASSETS_RATIO as a proxy for the LCR supports the idea that banks with liquid balance sheets display positive CARs with $t$-statistics between 3.494 and 4.268. The proxy for the NFSR, the CORE_FUNDING_RATIO, enters the regressions with a negative sign. ${ }^{22}$ This result empirically refutes Hypothesis 1 . The pecking order theory provides a plausible explanation for this result. Myers and Majluf (1984) posit that issuing equity is expensive, a prediction that finds ample support in empirical work (e.g., Cornett and Tehranian (1994)). As the CORE_FUNDING_RATIO is considerably influenced by Tier 1 capital, which increases banks' weighted average cost of capital (Baker and Wurgler (2015)), well capitalised banks may react negatively to the new standards because they are likely to be

\footnotetext{
We obtain qualitatively very similar results when we substitute the CORE_FUNDING_RATIO with the Tier 1 capital ratio. These tests are available from the authors.
} 
more resilient to liquidity shocks. ${ }^{23}$ Thus, they may be less willing to bear the additional costs of adjusting their asset/liability composition to comply with the new standards.

Shareholders of banks with more high quality capital seem to view liquidity regulation as particularly onerous and undesirable. To verify this statement empirically, we use an interaction between a CORE_FUNDING_RATIO_DUMMY (which takes on the value of 1 if the CORE_FUNDING_RATIO is above the 75th percentile, 0 otherwise) and our proxy for the LCR, the LIQUID_ASSETS_RATIO. In line with our interpretation, this interaction term enters significantly negatively, suggesting that banks with a large stable funding base are less exposed to liquidity shocks that may arise from a sudden dry ups of short-term funds.

Therefore, those banks are also less pressed to maintain large liquidity holdings to buffer such a shock.

The magnitude of the effect is considerable. The values from the second column in Table 4 for the coefficient on the CORE_FUNDING_RATIO indicate that moving from the sample's 25 th percentile to the 75 th percentile of the distribution of the CORE_FUNDING_RATIO is associated with a decline in the $(-1,1)$ CAR of $1.98 \%$ and 2.15\% for the models using the MSCI World and the MSCI Europe, respectively. The effects for the ratio of CUST_DEP_TO_TOT_ASSETS suggest increases in the $(-1,1)$ CAR of $2.88 \%$ for the MSCI World (2.91\% for the MSCI Europe). For the LIQUID_ASSETS_RATIO these values are $0.35 \%$ for the MSCI World, and $0.38 \%$ for the MSCI Europe. These results suggest that regulation on the LCR (as proxied by the LIQUID_ASSETS_RATIO) has had a relatively smaller impact on bank share prices than regulation on the NSFR (as proxied by the CORE_FUNDING_RATIO). A plausible

\footnotetext{
23 The correlation between the Tier 1 capital ratio and the CORE_FUNDING_RATIO is 0.59.
} 
interpretation for this result is that the regulation on LCR was severely dampened over time (especially in association with Event \#7).

We find some support for the hypothesis that charter values matter. While the coefficients on MARKET_TO_BOOK_RATIO remain insignificant, the coefficients on the ratio of Customer deposits to total assets are positive and significant, consistent with Hypothesis 3.

Next, we discuss country-level characteristics. Location at the periphery, approximated by the GIIPS dummy variable, and Eurozone membership do not affect the CARs or CMARs. ${ }^{24}$ However, pre-existing domestic liquidity regulation, government indebtedness, and the interbank market conditions play a role. The INTERBANK_RATIO is significantly positively related to the CARs and CMARs, suggesting that being domiciled in a country with

\footnotetext{
${ }^{24}$ It may be argued that banks located in highly-indebted countries, the GIIPS, may not be able to use their governments' debts as collateral to borrow from the European Central Bank at all, or only with large haircuts, to obtain the liquidity they need to satisfy liquidity requirements. To address this, we run our baseline regressions again after replacing the dummy variable GIIPS with GIIPSltimesGovernment bonds, where Government bonds is the ratio of government bonds to total assets. As explained by Gennaioli, Martin, and Rossi (2014), while BankScope does not provide a breakdown of government bonds by nationality, more than $75 \%$ of banks' bondholdings correspond to domestic bonds. Therefore, the interaction between GIIPS and
} GOVERNMENT_BONDS captures the effect of holding a large portion of assets in bonds issued by GIIPS countries. The coefficients on GIIPS $\times$ GOVERNMENT_BONDS are large and significantly negative. Results are available from the authors. In unreported tests, we also examine if Eurozone banks are more strongly affected during the Eurozone crisis to further examine the two-way feedback loop. We use an interaction term between EUROZONE and a dummy for CRISIS years that takes on the value of one in the years from 2010 onwards. The magnitude of the coefficient on the interaction term is larger than for the EUROZONE dummy in the main specification, reinforcing the view that the nexus between banking conditions and sovereign debt amplifies the stock price reactions. 
tighter funding conditions in the interbank market decreases the CARs and CMARs. This result is consistent with Hypothesis 4. There is also some evidence of negative effects from pre-existing domestic liquidity regulation which supports Hypothesis 7A. The coefficients indicate that shareholders of banks in countries that already had some form of liquidity regulation in place experience more negative wealth effects. The fact that bank-specific variables are more robustly associated than country-level variables with abnormal returns is not surprising. Bank-level characteristics are likely to play a greater role for the crosssectional variation in stock price returns than country-level characteristics.

\section{[TABLE 5: COUNTRY AND BANK-LEVEL CHARACTERISTICS AND CARs - LIQUIDITY ONLY BUCKET]}

\section{Liquidity only Bucket}

Table 5 replicates these regressions but excludes the Events \#4, \#5, and \#6 to focus on the Liquidity only bucket. Our findings are similar.

\section{Further Robustness and Falsification Tests}

A potential concern using event study methodology is that the news released by the BCBS coincide with bank-specific events such as earnings announcements, ratings downgrades, and changes in corporate governance structures which also affect share prices. To rule out such concerns, we screen the international press via LEXIS/NEXIS and use the following keywords: dividends, earnings, CEO, losses, write-downs, restatement, downgrade, rating, fraud, annual report, manipulate, inspection, restructuring, M\&A, merger, acquisition, stock split, dilution, fired, restructuring, issue, takeover. We then replicate the regressions from Tables 4 and 5 but exclude banks for which our news search suggests the presence of confounding events over a 3-day window, centred on the event day. Our findings remain 
unchanged. These tests are relegated to the Internet Appendix, Tables A.2 and A.3.

While our main tests already correct for heteroskedasticity, equation (1) may not sufficiently capture the impact of volatility changes on the standard errors. The phenomenon that volatility tends to cluster can undermine the assumption of constant variance. If volatility increases around the announcement days we study and we ignore such volatility clustering, we may unintentionally over-reject the null hypothesis (Boehmer (1991)). To address this issue, Internet Appendix, Table A.4, shows tests based on GARCH modelling. ${ }^{25}$ Our inferences remain unchanged when all seven events are considered. Likewise, the results for the cross-sectional determinants of the CARs and CMARs remain unaltered when we exclude the announcements associated with a negative effect on the probability to impose stricter liquidity rules (i.e., Event \#5 and \#7).

\section{Falsification Tests}

Prior to offering some concluding remarks, we embark upon a falsification exercise. This analysis raises the question of whether the effects we capture are limited to bank stocks.

We run the tests from Table 3 but use the national indices (see Appendix D) instead of the portfolios of bank stocks to calculate CARs and CMARs. The idea is to analyze whether other firms, i.e., non-financial corporations, are affected by the announcements by the BCBS.

25 We estimate the market model similar to equation (1), but according to an AR(1)-GARCH(1,1) model instead of a Prais-Winsten model. The conditional mean equation is estimated as follows:

$R_{i, t}=\alpha_{i}+\beta_{i} R_{m, t}+\rho R_{i, t-1}+\sum_{d=2}^{5} \lambda_{d} D_{d}+\varepsilon_{i, t}$

The conditional variance equation is estimated according to:

$h_{i, t}=\gamma_{0}+\gamma_{1}\left(\varepsilon_{i, t-1}\right)^{2}+\gamma_{2} h_{i, t-1}$.

The daily abnormal returns are the residuals of the conditional mean equation. 
The results are shown in Table A.5 of the Internet Appendix. Out of 18 tests in Panel A that focus on CARs, only the analyses for Belgium, Luxembourg, and the United Kingdom enter weakly significantly, all other tests remain insignificant. Focusing on the Liquidity only bucket further strengthens these inferences: we only find significant effects for the United Kingdom. Panel B reports on CMARs. We only find one significant association for the full sample (Luxembourg), and one for the Liquidity only bucket (United Kingdom). Thus, for most of the countries in the sample, we can rule out any simultaneous effects for other listed companies arising from liquidity regulation.

\section{VII.Concluding Remarks}

In this paper, we use event study methodology to present the first analysis of the effect of bank liquidity regulation, a major innovation of the Basel III framework, on bank stock prices. Central to this landmark event in banking regulation are two new ratios that address liquidity risk, the NSFR and the LCR.

The regulatory process leading to the introduction of liquidity regulation consists of seven separate but related announcements by the BCBS. Over a time horizon of approximately five years, the BCBS made several amendments and revisions to the initial proposal in response to comments received by the banking industry. We exploit this gradual release of new information about details of the new regulation to establish the effects on shareholder wealth in terms of CARs and CMARs for listed banks in Europe.

While proponents of liquidity regulation place great emphasis on pointing out the role of global liquidity standards for banking system soundness, the controversial debate and criticism highlighted by the banking industry in the run-up to the implementation of the new rules suggests that regulating liquidity is considered to be costly. 
Our first set of results indeed suggests that market participants respond negatively to announcements about bank liquidity regulation. This finding is consistent with the view that complying with liquidity regulations interferes with banks' asset and liability choices and ultimately reduces profits. However, further tests that separate out stock price reactions to liquidity regulation from responses to announcements to capital regulation and other aspects of Basel III which occur at the same time and are contained in the same press release, weaken these inferences and the average stock price reaction is at best weakly significant. Two reasons may be responsible for the weaker inferences: First, the long time horizon until the rules are fully enforced may have led markets to believe that the new regulation is not (yet) binding, and therefore only of marginal value relevance at the timing of the press release. This may be further amplified by the challenges posed by any new regulation: banks can only gradually build the competencies and procedures to comply with the rules and may not yet fully comprehend the ramifications that arise from liquidity regulation. Second, and more importantly, while liquidity regulation is likely to gradually become an important tool of the regulatory framework, capital regulation currently remains the dominant component of Basel II, both in terms of what is considered by markets to be binding and in terms of value relevance. What our tests for the Liquidity only bucket indicate is that liquidity regulation currently has some, yet limited potential to affect bank conduct above and beyond capital regulation. Therefore, these findings can be viewed to constitute suggestive evidence that regulating bank liquidity is a complement to capital regulation.

In addition, our data support the view on regulation according to which not all regulated firms are equally affected. Bank-specific characteristics such as the liquidity of balance sheets and the exposure to funding mismatch decrease negative stock price reactions. We also find 
some support for theories about the role of charter values which posit that holding liquidity insures charter values. Country-specific characteristics also play some role. The two-way feedback loop between the domestic banking industry and the sovereign's creditworthiness affects shareholder wealth effects. High government indebtedness and strained funding conditions in the domestic interbank market reinforce each other, and banks from countries with these characteristics display bigger share price reactions than elsewhere in Europe. The cumulative abnormal returns are lower in countries if banks were subject to domestic liquidity regulation that was in place prior to the announcements by the BCBS.

Clearly, our initial exploration of the market reaction towards the introduction of quantity regulation of bank liquidity can only be viewed as a starting point for a more comprehensive research agenda that explores the effects of liquidity regulation. Ultimately, more work is required to better understand how the new rules will affect bank conduct, and asset and liability composition. Additional work is also needed to establish how the new rules affect the soundness of individual banks and the financial system on the whole. We leave these questions for future research. 


\section{References}

Acharya, V. V.; I. Drechsler; and P. Schnabl. "A Pyrrhic Victory? - Bank Bailouts and Sovereign Credit Risk.” Journal of Finance, 69 (2014), 2689-2739.

Acharya, V. V., and O. Merrouche. "Precautionary Hoarding of Liquidity and Interbank Markets: Evidence from the Subprime Crisis.” Review of Finance, 17 (2013), 107-160. Aiyar, S.; C. W. Calomiris; J. Hooley; Y. Korniyenko; and T. Wieladek. "The International Transmission of Bank Capital Requirements: Evidence from the UK.” Journal of Financial Economics, 113 (2014), 368-382.

Allen, P. R., and W. J. Wilhelm. "The Impact of the 1980 Depository Institutions Deregulation and Monetary Control Act on Market Value and Risk: Evidence from the Capital Markets.” Journal of Money, Credit and Banking, 20 (1988), 364-380.

Armour, J.; C. Mayer; and A. Polo. "Regulatory Sanctions and Reputational Damage in Financial Markets.”Journal of Financial Quantitative Analysis, forthcoming.

Armstrong, C.; M. Barth; A. Jagolinzer; and E. Riedl. "Market Reaction to the Adoption of IFRS in Europe.” Accounting Review, 85 (2010), 31-62.

Baker, M. P., and J. Wurgler. "Do Strict Capital Requirements Raise the Cost of Capital? Banking Regulation and the Low Risk Anomaly.” American Economic Review, 105 (2015), 315-320.

Banerjee, R., and H. Mio. "The Impact of Liquidity Regulation on Banks.” Bank of England Staff Working Paper No 536 (2015).

Barth, J. R.; G. Caprio; and R. Levine. "Bank Supervision and Regulation: What Works Best?” Journal of Financial Intermediation, 13 (2004), 205-248. 
Bayazitova, D., and A. Shivdasani. “Assessing TARP.” Review of Financial Studies, 25 (2012), 377-407.

Beck, T., R. Todorov, and W. Wagner. "Supervising Cross-Border Banks: Theory, Evidence and Policy.” Economic Policy, 28 (2013), 5-44.

Boehmer, E. "Event-Study Methodology under Conditions of Event-Induced Variance." Journal of Financial Economics, 30 (1991), 253-272.

Brown, S. J., and J. B. Warner. "Measuring Security Price Performance.” Journal of Financial Economics, 8 (1980), 205-258.

Calomiris, C.; F. Heider; and M. Hoerova. "A Theory of Bank Liquidity Requirements." Working Paper, Columbia University (2015).

Cifuentes, R.; G. Ferrucci; and H. S. Shin. "Liquidity Risk and Contagion.” Journal of the European Economic Association, 3 (2005), 556-566.

Cihak, M.; A. Demirgüç-Kunt; M. S. Martinez Peria; and A. Mohseni-Cheraghlou. "Bank Regulation and Supervision around the World: A Crisis Update”. World Bank Policy Research Working Paper No 6286 (2012).

Cornett, M. M.; J. J. McNutt; P. E. Strahan; and H. Tehranian. "Liquidity Risk Management and Credit Supply in the Financial Crisis.” Journal of Financial Economics, 101 (2011), $297-312$.

Cornett, M. M., and H. Tehranian. “An Examination of Voluntary versus Involuntary Security Issuance by Commercial Banks: The Impact of Capital Regulations on Common Stock Returns.” Journal of Financial Economics, 35 (1994), 99-122.

Dann, L. and C. James. "An Analysis of the Impact of Deposit Rate Ceilings on the Market Values of Thrift Institutions.” Journal of Finance, 37 (1982), 1259-1275. 
De Haan, L., and J. W. van den End. "Bank Liquidity, the Maturity Ladder, and Regulation." De Nederlandsche Bank Working Paper No 346 (2012).

Demirgüç-Kunt, A.; E. Detragiache; and T. Tressel. "Banking on the Principles: Compliance with Basel Core Principles and Bank Soundness.” Journal of Financial Intermediation, 17 (2008), 511-542.

Duijm, P., and P. Wierts. "The Effects of Liquidity Regulation on Bank Assets and Liabilities.” International Journal of Central Banking, 12 (2016), 385-411.

European Banking Authority (EBA). "Results of the Basel III Monitoring Exercise Based on Data as of 31 December 2011." September (2012).

Focarelli, D.; A. F. Pozzolo; and L. Casolaro. "The Pricing Effect of Certification on Syndicated Loans.” Journal of Monetary Economics, 55 (2008), 335-349.

Fullenkamp, C., and C. Rochon. "Reconsidering Bank Capital Regulation: A New Combination of Rules, Regulators, and Market Discipline.” Journal of Economic Policy Reform (2016).

Fuller, K.; J. Netter; and M. Stegemoller. "What Do Returns to Acquiring Firms Tell Us? Evidence from Firms that Make Many Acquisitions.” Journal of Finance, 57 (2002), $1763-1793$

Gennaioli, N., A. Martin, and S. Rossi. "Banks, Government Bonds, and Default: What Do the Data Say?” IMF Working Paper No 120 (2014).

Glaeser, E. L., and A. Shleifer. “A Reason for Quantity Regulation.” American Economic Review, 91 (2001), 431-435.

Goyal, V. K. "Market Discipline of Bank Risk: Evidence from Subordinated Debt Contracts." Journal of Financial Intermediation, 14 (2005), 318-350. 
Horváth, B., and H. Huizinga. "Does the European Financial Stability Facility Bail Out Sovereigns or Banks? An Event Study.” Journal of Money, Credit, and Banking, 47 (2015), 177-206.

Institute of International Finance (IIF). "Specific Impacts of Regulatory Change on EndUsers.” Initial Report (2012).

James, C. M. "An Analysis of Intra-Industry Differences in the Effect of Regulation: The Case of Deposit Rate Ceilings.” Journal of Monetary Economics, 12 (1983), 417-432.

Jensen, M. C. "Agency Cost of Free Cash Flow, Corporate Finance, and Takeovers.” American Economic Review, 76 (1986), 323-329.

Kaplanski, G., and H. Levy. "Sentiment and Stock Prices: The Case of Aviation Disasters." Journal of Financial Economics, 95 (2010), 174-201.

Keeley, M. C. "Deposit Insurance, Risk, and Market Power in Banking." American Economic Review, 80 (1990), 1183-1200.

Lane, P. R. "The European Sovereign Debt Crisis.” Journal of Economic Perspectives, 26 (2012), 49-68.

Le Leslé, V. “Bank Debt in Europe: Are Funding Models Broken?” IMF Working Paper No 299 (2012).

Lucas, A.; B. Schwaab; and X. Zhang. "Conditional Euro Area Sovereign Default Risk." Journal of Business and Economic Statistics, 32 (2014), 271-284.

Myers, S. C., and R. G. Rajan. "The Paradox of Liquidity." Quarterly Journal of Economics, 113 (1998), 733-771.

Needham, D. “The Economics and Politics of Regulation: A Behavioral Approach.” Boston, MA: Little, Brown and Company (1983). 
Norden, L.; P. Roosenboom; and T. Wang. "The Impact of Government Intervention in Banks on Corporate Borrowers' Stock Returns.” Journal of Financial and Quantitative Analysis, 48 (2013), 1635-1662.

Peltzman, S. “Toward a More General Theory of Regulation.” Journal of Law and Economics, 19 (1976), 211-241.

Ratnovski, L. "Bank Liquidity Regulation and the Lender of Last Resort." Journal of Financial Intermediation, 18 (2009), 541-558.

Santos, A. O, and D. Elliott. "Estimating the Costs of Financial Regulation." IMF Staff Discussion Note, 11 September (2012).

Schwert, G. W. "Using Financial Data to Measure Effects of Regulation.” Journal of Law and Economics, 24 (1981), 121-158.

Slovin, M. B.; M. E. Sushka; and Y. M. Bendeck. "The Market Valuation Effects of Reserve Regulation.” Journal of Monetary Economics, 25 (1990), 3-19.

Stigler, G. J. "The Theory of Economic Regulation.” Bell Journal of Economics and Management Science, 2 (1971), 3-21.

Strahan, P. E. "Liquidity Risk and Credit in the Financial Crisis." FRBSF Economic Letter 15, 14 May (2012).

Wagster, J. D. "Impact of the 1988 Basle Accord on International Banks." Journal of Finance, 51 (1996), 1321-1346. 


\section{Appendix A. The Liquidity Standards}

The liquidity coverage ratio aims to ensure that a bank has an adequate stock of unencumbered high quality liquid assets which consists of cash or assets that can be converted into cash at little or no loss of value in private markets to meet its liquidity needs for a 30 calendar-day liquidity stress scenario:

$$
\text { LCR }=\frac{\text { Stock of HQLA }}{\text { Total Net Cash Outflows over the Next } 30 \text { Calendar Days }} \geq 100 \%
$$

As in its final version (Jan. 7, 2013), in order to qualify as HQLA (the numerator of the ratio), assets should be liquid in markets during a time of stress and, in most cases, be eligible for use in central bank operations. HQLA are comprised of Level 1 and Level 2 assets. Level 2 are subject to limits and a range of haircuts conditional on their market liquidity.

The denominator of the LCR is the total net cash outflows, i.e. total expected cash outflows, minus total expected cash inflows. Expected cash outflows (inflows) are calculated by multiplying the outstanding balances of various categories or types of liabilities and off-balance sheet commitments with the rates at which they are expected to run off or be drawn down. ${ }^{26}$ Banks are expected to meet this requirement on an on-going basis. However, during a period of financial stress, banks are allowed to use their stock of HQLA, thereby falling below $100 \%{ }^{27}$ The standard was introduced on Jan. 1, 2015 , but a gradual approach will be followed as the minimum requirement will be initially set at $60 \%$ in order to rise in equal annual steps to reach $100 \%$ on Jan. 1, 2019, as reported below:

\footnotetext{
26 Total cash inflows are subject to an aggregate cap of $75 \%$ of total expected cash outflows, thereby ensuring a minimum level of HQLA holdings at all times.

27 Nonetheless, the LCR standard is intended as a minimum level of liquidity for internationally active banks; national authorities may require higher minimum level of liquidity, especially if they deem that the LCR does not adequately reflect the liquidity risks that supervised banks face.
} 


\begin{tabular}{|c|c|c|c|c|}
\hline Jan. 1, 2015 & Jan. 1, 2016 & Jan. 1, 2017 & Jan. 1, 2018 & Jan. 1, 2019 \\
\hline Minimum LCR $=$ & Minimum LCR $=$ & Minimum LCR $=$ & Minimum LCR $=$ & Minimum LCR = \\
$60 \%$ & $70 \%$ & $80 \%$ & $90 \%$ & $100 \%$ \\
\hline
\end{tabular}

The net stable funding ratio (NSFR) establishes a minimum acceptable amount of stable funding based on the liquidity characteristics of an institution's assets and activities over a one year horizon. The NSFR aims to limit over-reliance on wholesale funding during times of buoyant market liquidity and encourage better assessment of liquidity risk across all on- and off-balance sheet items. In addition, the NSFR approach would help to counterbalance incentives for institutions to fund their stock of liquid assets with short-term funds that mature just outside the supervisory defined horizon for that metric. The standard is expressed as the ratio:

$$
\text { NSFR }=\frac{\text { Available Amount of Stable Funding }}{\text { Required Amount of Stable Funding }} \geq 100 \%
$$

As for the numerator, "Stable Funding" are those types and amounts of equity and liability financing expected to be reliable sources of funds over a one-year time horizon under conditions of extended stress. The amount of such funding required for a specific institution (the denominator of the ratio) is a function of the liquidity characteristics of various types of assets, off-balance sheet contingent exposures, and/or the activities pursued by the institution. Liabilities and assets are weighted according to their stability and liquidity characteristics, respectively. The standard will be introduced by Jan. 1, 2018. 


\section{Appendix B. Event Descriptions}

\section{Event}

1 (Feb. 21, 2008)

2 (June 17, 2008)

3 (Sept. 25, 2008)

4 (Dec. 17, 2009)

\section{Description}

The BCBS releases a document entitled Liquidity Risk: Management and Supervisory Challenges. It summarizes the key findings of a study carried out by the Working Group on Liquidity and aimed to review banks' liquidity risk management strategies as well as liquidity supervision practices in member countries.

The BCBS issues for public comment the document on enhanced global Principles for Sound Liquidity Risk Management and Supervision. This guidance discusses the key elements of a robust framework for liquidity risk management. Such elements include: board and senior management oversight; the establishment of policies and risk tolerance; the use of liquidity risk management tools such as comprehensive cash flow forecasting, limits and liquidity scenario stress testing; the development of robust and multifaceted contingency funding plans; and the maintenance of a sufficient cushion of high quality liquid assets to meet contingent liquidity needs.

Global bank supervisors endorse strengthened sound practice standards for liquidity risk management and supervision. The final document on Principles for Sound Liquidity Risk Management is released.

The BCBS issues for consultation a package of proposals to strengthen global capital and liquidity regulations with the goal of promoting a more resilient banking sector. As far as bank liquidity is concerned, the International Framework for Liquidity Risk Measurement, Standards and Monitoring (consultative document) is released. The document introduces two internationally consistent liquidity standards (the LCR and NSFR). It also comprises a set of common metrics that should be considered as the minimum types of information which supervisors should use in monitoring the liquidity risk profiles of supervised entities. The proposed set of monitoring tools refers in 
particular to: contractual maturity mismatch; concentration of funding; available unencumbered assets; market-related monitoring tools. The Group of Governors and Heads of Supervision (GHOS), the oversight body of the BCBS, meets to review the BCBS capital and liquidity reform package. Main revisions on the liquidity rules deal with: i) LCR: relaxing the definition of qualifying liquid assets (e.g., by including high quality corporate bonds and covered bonds) and introducing a more favourable treatment of certain liabilities (e.g., a lower run-off rate floor for retail and small-medium-enterprise (SME) deposits); ii) NSFR: a more favourable treatment of the retail business (e.g., by increasing the available stable funding factor for retail and SME deposits and lowering the required stable funding ratio for residential mortgages). However, at this stage the BCBS states that both standards require further observation and a number of adjustments. As for the LCR examples of measures to be refined include the development of standards for jurisdictions which do not have sufficient Level 1 assets to meet the standard; the introduction of a percentage factor to measure cash inflows; a clearer definition of operational activities with financial institution counterparties (e.g., custody, clearing and settlement, cash management activities). The BCBS declares that the NSFR requires an "observation phase" to address any unintended consequences across business models or funding structures before finalising and introducing the revised NSFR as a minimum standard by Jan. 1, 2018.

6 (Dec. 16, 2010) The BCBS issues the Basel III rules text, presenting the details of global regulatory standards on bank capital adequacy and liquidity agreed by the GHOS and endorsed by the G20 Leaders at their November summit in Seoul. The BCBS also publishes the results of its comprehensive quantitative impact study. In particular, the final version of the document Basel III: International Framework for Liquidity Risk Measurement, Standards and Monitoring is released. The document incorporates and refines 
amendments announced in broad terms in July 2010. No substantial changes have been made to the NSFR. and Liquidity Risk Monitoring Tools following endorsement on Jan. 6, 2013 by the GHOS. The revisions to the LCR developed and agreed by the BCBS over the past two years include an expansion in the range of assets eligible as HQLA and some refinements to the assumed inflow and outflow rates to better reflect actual experience in times of stress.

The main measures are summarized as follows:

i) the expansion of the list of HQLA by the introduction of Level $2 \mathrm{~B}$ assets (subject to higher haircuts and a limit of $15 \%$ of total HQLA), including corporate debt securities rated $\mathrm{A}+$ to $\mathrm{BBB}-$ and certain unencumbered equities (both subject to a $50 \%$ haircut), certain residential mortgage-backed securities rated AA or higher (with a 25\% haircut); ii) a more favourable treatment of: insured deposits, by a lower outflow on certain types of fully insured retail deposits (from 5\% to 3\%); of fully insured non-operational deposits from non-financial corporates, sovereigns, central banks and public sector entities (from $40 \%$ to $20 \%$ ), "non-operational" deposits provided by non-financial corporates, sovereigns, central banks, and public sector entities (from $75 \%$ to $40 \%$ ); iii) a more favourable treatment of committed liquidity facilities to non-financial corporates with the reduction of the drawdown rate on the unused portion of committed liquidity facilities to non-financial corporates, sovereigns central banks, and public sector entities (from $100 \%$ to $30 \%$ ). Similarly, a better treatment has been applied to interbank credit and liquidity facilities (distinguished from inter-financial credit facilities), in order to reduce the outflow rate on the former from $100 \%$ to $40 \%$; iv) a better treatment of central bank operations by reducing the outflow rate on maturing secured funding transactions with central banks from $25 \%$ to $0 \%$; trade finance, including guidance to indicate that a low outflow rate $(0 \%-5 \%)$ is expected to apply; 
v) a new and standardized treatment for derivatives positions, comprising additional derivatives risks included in the LCR with a $100 \%$ outflow (relates to collateral substitution, and excess collateral that the bank is contractually obligated to return/provide if required by a counterparty); a standardised approach for liquidity risk related to market value changes in derivatives positions; net outflow of $0 \%$ for derivatives (and commitments) that are contractually secured/collateralised by HQLA. In addition, the BCBS has agreed a revised timetable to phase in the standard and to give effect to the BCBS intention for the stock of liquid assets to be used. 
Appendix C. Banks without Deposits or with Negative Equity for One or More Years. Ageas SA/NV, Alpha Bank AE, Azimut Holding SpA, Bankia SA, Brewin Dolphin Holdings Plc, Eurobank Ergasias SA, Exor Spa, Groupe Bruxelles Lambert, Institut Régional de Dévelopement de la Région Nord Pas-de-Calais-I.R.D. Nord Pas-de-Calais, Marfin Investment Group, National Bank of Greece SA, Paragon Group of Companies Plc, Pargesa Holding SA, Piraeus Bank SA, Robeco NV, Sampo Plc, SOFIBUS Patrimoine, Swiss Life Holding, Tekfen Holding AS, Cofitem - Cofimur.

\section{Appendix D. National Market Indices.}

Italy: FTSE MIB INDEX - PRICE INDEX

Germany: CDAX GENERAL 'KURS' - PRICE INDEX

Greece: DJGL GREECE DJTM GREECE - PRICE INDEX

Portugal: PORTUGAL-DS Market - PRICE INDEX

Spain: IBEX 35 - PRICE INDEX

Ireland: IRELAND SE OVERALL (ISEQ) - PRICE INDEX

United Kingdom: FTSE 250 - PRICE INDEX

Switzerland: FTSE SWITZERLAND - PRICE INDEX

France: FRANCE CAC 40 - PRICE INDEX

Sweden: OMX STOCKHOLM 30 (OMXS30) - PRICE INDEX

Belgium: BEL ALL SHARE - PRICE INDEX

Austria: DJGL AUSTRIA DJTM AUSTRIA - PRICE INDEX

Cyprus: CYPRUS GENERAL - PRICE INDEX

Denmark: OMX COPENHAGEN (OMXC20) - PRICE INDEX 
Finland: OMX HELSINKI (OMXH) - PRICE INDEX

Luxembourg: LUXEMBOURG SE GENERAL - PRICE INDEX

Malta: MALTA SE MSE - PRICE INDEX

Netherlands: AEX ALL SHARE - PRICE INDEX 


\section{TABLE 1}

\section{Events and Predicted Effects on Probability of Stricter Rules after Each Event}

Table 1 shows the event dates, and we also provide a brief description for each event. The

final column gives an overview about whether the event increased or decreased the

probability to introduce stricter rules for liquidity regulation.

\begin{tabular}{|c|c|c|c|}
\hline Event Date & Short Description & $\begin{array}{l}\text { Probability to Introduce } \\
\text { Stricter Rules }\end{array}$ & $\begin{array}{l}\text { Expected Effect on } \\
\text { Bank Stock Prices }\end{array}$ \\
\hline Feb. 21, 2008 & $\begin{array}{c}\text { Release of Liquidity Risk: } \\
\text { Management and Supervisory } \\
\text { Challenge }\end{array}$ & Increased & Negative \\
\hline June 17, 2008 & $\begin{array}{l}\text { Release of Principles for } \\
\text { Sound Liquidity Risk } \\
\text { Management and Supervision }\end{array}$ & Increased & Negative \\
\hline Dec. 17, 2009 & $\begin{array}{l}\text { Management and Supervision } \\
\text { Release of International } \\
\text { Framework for Liquidity Risk } \\
\text { Measurement, Standards and } \\
\text { Monitoring }\end{array}$ & Increased & Negative \\
\hline July 26, 2010 & $\begin{array}{l}\text { Release of the July } 2010 \\
\text { Annex, containing the key } \\
\text { broad agreements of the } \\
\text { Governors and Heads of } \\
\text { Supervision }\end{array}$ & Decreased & Positive \\
\hline Dec. 16,2010 & $\begin{array}{l}\text { Release of Basel III: } \\
\text { International Framework for } \\
\text { Liquidity Risk Measurement, } \\
\text { Standards and Monitoring }\end{array}$ & Increased & Negative \\
\hline Jan. 7, 2013 & $\begin{array}{c}\text { Release of Basel III: The } \\
\text { Liquidity Coverage Ratio and } \\
\text { Liquidity Risk Monitoring } \\
\text { Tools }\end{array}$ & Decreased & Positive \\
\hline
\end{tabular}




\section{TABLE 2}

\section{Sample Composition by Country, Representativeness, and Descriptive Statistics}

Table 2 reports in Panel A details for the composition of the sample. We present the number of banks by country, and we report on whether the banks headquartered in these countries are from the EU, the Eurozone, the GIIPS, or were subject to domestic liquidity regulation that precedes the new rules issued by the BCBS. We also present details about the representativeness of the sample for coverage in terms of total banking system assets, loans, and deposits, and we show how many banks fall under the SSM led by the ECB. Panel B presents descriptive statistics in terms of means and standard deviations by country for the bank and country-specific variables in our regressions.

$\underline{\text { Panel A. Sample Composition for Country-Based Portfolio }}$

\begin{tabular}{|c|c|c|c|c|c|c|c|c|c|}
\hline & Banks & $\mathrm{EU}$ & Eurozone & GIIPS & $\begin{array}{c}\text { Pre-Existing } \\
\text { Domestic } \\
\text { Liquidity Regulation } \\
\end{array}$ & $\begin{array}{c}\text { Coverage in } \\
\% \text { of Total } \\
\text { Banking } \\
\text { System } \\
\text { Assets } \\
\end{array}$ & $\begin{array}{c}\text { Coverage in } \\
\% \text { of Total } \\
\text { Banking } \\
\text { System } \\
\text { Loans } \\
\end{array}$ & $\begin{array}{c}\text { Coverage in } \\
\% \text { of Total } \\
\text { Banking } \\
\text { System } \\
\text { Deposits } \\
\end{array}$ & $\begin{array}{c}\text { No. of } \\
\text { Banks } \\
\text { under } \\
\text { the } \\
\text { SSM }\end{array}$ \\
\hline Austria & 6 & YES & YES & NO & NO & $28.38 \%$ & $34.97 \%$ & $22.82 \%$ & 2 \\
\hline Belgium & 2 & YES & YES & NO & NO & $36.87 \%$ & $42.45 \%$ & $9.34 \%$ & 2 \\
\hline Cyprus & 2 & YES & YES & NO & NO & $42.90 \%$ & $49.60 \%$ & $38.74 \%$ & 2 \\
\hline Denmark & 29 & YES & NO & NO & NO & $60.89 \%$ & $56.88 \%$ & $56.21 \%$ & $\mathrm{n} / \mathrm{a}$ \\
\hline Finland & 3 & YES & YES & NO & YES & $13.18 \%$ & $16.16 \%$ & $8.30 \%$ & 1 \\
\hline France & 7 & YES & YES & NO & NO & $42.27 \%$ & $32.72 \%$ & $15.02 \%$ & 6 \\
\hline Germany & 10 & YES & YES & NO & YES & $54.89 \%$ & $52.17 \%$ & $25.75 \%$ & 5 \\
\hline Greece & 7 & YES & YES & YES & NO & $66.22 \%$ & $69.01 \%$ & $22.21 \%$ & 5 \\
\hline Ireland & 2 & YES & YES & YES & NO & $50.05 \%$ & $62.88 \%$ & $28.26 \%$ & 2 \\
\hline Italy & 14 & YES & YES & YES & NO & $68.70 \%$ & $75.04 \%$ & $49.38 \%$ & 5 \\
\hline Luxembourg & 3 & YES & YES & NO & NO & $9.11 \%$ & $21.40 \%$ & $3.78 \%$ & 0 \\
\hline Malta & 2 & YES & YES & NO & NO & $68.47 \%$ & $84.90 \%$ & $40.96 \%$ & 1 \\
\hline Netherlands & 5 & YES & YES & NO & YES & $34.89 \%$ & $33.94 \%$ & $11.22 \%$ & 2 \\
\hline Portugal & 4 & YES & YES & YES & NO & $52.23 \%$ & $55.41 \%$ & $21.87 \%$ & 2 \\
\hline Spain & 7 & YES & YES & YES & NO & $81.26 \%$ & $82.58 \%$ & $22.70 \%$ & 5 \\
\hline Sweden & 4 & YES & NO & NO & NO & $91.66 \%$ & $90.56 \%$ & $77.73 \%$ & $\mathrm{n} / \mathrm{a}$ \\
\hline Switzerland & 13 & $\mathrm{NO}$ & NO & NO & YES & $62.83 \%$ & $58.84 \%$ & $45.20 \%$ & $\mathrm{n} / \mathrm{a}$ \\
\hline United Kingdom & 8 & YES & NO & NO & YES & $67.85 \%$ & $61.75 \%$ & $60.31 \%$ & $\mathrm{n} / \mathrm{a}$ \\
\hline Total Banks & 128 & 115 & 74 & 34 & 21 & $57.22 \%$ & $56.97 \%$ & $38.59 \%$ & 40 \\
\hline
\end{tabular}


TABLE 2 (continued)

Panel B. Means and Standard Deviations of Key Variables by Country and for the Full Sample

\begin{tabular}{lcccccccccccc} 
& \multicolumn{3}{c}{ Austria } & \multicolumn{2}{c}{ Belgium } & \multicolumn{3}{c}{ Cyprus } & \multicolumn{2}{c}{ Denmark } \\
\cline { 2 - 10 } & Mean & SD & Mean & SD & Mean & SD & Mean & SD & Mean & SD \\
\hline INTERBANK_RATIO & 0.184 & 0.0914 & 0.2187 & 0.0893 & 0.0758 & 0.0608 & 0.1385 & 0.1074 & 0.1495 & 0.0785 \\
DEBT_TO_GDP_RATIO & 0.0067 & 0.0005 & 0.0085 & 0.0003 & 0.0111 & 0.0019 & 0.0036 & 0.0008 & 0.0040 & 0.0006 \\
LIQUID_ASSETS_RATIO & 0.22 & 0.1101 & 0.2943 & 0.069 & 0.2009 & 0.072 & 0.2691 & 0.3095 & 0.3050 & 0.2445 \\
CORE_FUNDING_RATIO & 0.6433 & 0.0879 & 0.3223 & 0.1859 & 0.7817 & 0.1179 & 0.7176 & 0.1846 & 0.4032 & 0.1934 \\
MARKET_TO_BOOK_RATIO & 0.9851 & 0.3721 & 0.6396 & 0.927 & 0.9268 & 0.6981 & 0.9518 & 0.5425 & 0.9347 & 0.2916 \\
CUS_DEP_TO_TOT_ASSETS & 0.5894 & 0.109 & 0.2883 & 0.1758 & 0.7163 & 0.1082 & 0.6146 & 0.1643 & 0.3643 & 0.1989
\end{tabular}

\begin{tabular}{lcccccccccccc} 
& \multicolumn{3}{c}{ France } & \multicolumn{2}{c}{ Germany } & \multicolumn{3}{c}{ Greece } & \multicolumn{2}{c}{ Ireland } \\
\cline { 2 - 9 } & Mean & SD & Mean & SD & Mean & SD & Mean & SD & Mean & SD \\
\hline INTERBANK_RATIO & 0.1715 & 0.1092 & 0.1390 & 0.0952 & 0.1691 & 0.1426 & 0.0836 & 0.0770 & 0.2062 & 0.2422 \\
DEBT_TO_GDP_RATIO & 0.0079 & 0.001 & 0.0047 & 0.0006 & 0.0123 & 0.0008 & 0.0065 & 0.0026 & 0.0109 & 0.0007 \\
LIQUID_ASSETS_RATIO & 0.5838 & 0.3121 & 0.4387 & 0.404 & 0.1405 & 0.0645 & 0.1541 & 0.0642 & 0.3291 & 0.2439 \\
CORE_FUNDING_RATIO & 0.3384 & 0.2306 & 0.5494 & 0.2428 & 0.6374 & 0.1018 & 0.5132 & 0.0536 & 0.4836 & 0.2044 \\
MARKET_TO_BOOK_RATIO & 1.2679 & 1.2126 & 1.0688 & 0.6248 & 1.1005 & 0.4579 & 0.7969 & 0.7586 & 1.1835 & 1.193 \\
CUS_DEP_TO_TOT_ASSETS & 0.3250 & 0.2294 & 0.5051 & 0.2448 & 0.5759 & 0.0830 & 0.4490 & 0.045 & 0.4129 & 0.1823
\end{tabular}

\begin{tabular}{lcccccccccc} 
& \multicolumn{2}{c}{ Luxembourg } & \multicolumn{2}{c}{ Malta } & \multicolumn{2}{c}{ Netherlands } & \multicolumn{2}{c}{ Portugal } & \multicolumn{2}{c}{ Spain } \\
\cline { 2 - 10 } & Mean & SD & Mean & SD & Mean & SD & Mean & SD & Mean & SD \\
\hline INTERBANK_RATIO & 0.0807 & 0.0498 & 0.0365 & 0.0343 & 0.0800 & 0.0508 & 0.1211 & 0.0790 & 0.0700 & 0.0749 \\
DEBT_TO_GDP_RATIO & 0.0013 & 0.0005 & 0.0099 & 0.0038 & 0.0053 & 0.0007 & 0.0082 & 0.0010 & 0.0042 & 0.0009 \\
LIQUID_ASSETS_RATIO & 0.8115 & 1.0784 & 0.31 & 0.0499 & 0.4250 & 0.8088 & 0.1864 & 0.0668 & 0.1916 & 0.1213 \\
CORE_FUNDING_RATIO & 0.3438 & 0.2656 & 0.8076 & 0.0242 & 0.4571 & 0.2523 & 0.5256 & 0.0788 & 0.4573 & 0.0633 \\
MARKET_TO_BOOK_RATIO & 1.3519 & 2.0375 & 2.1406 & 1.1298 & 0.8612 & 0.5131 & 1.1049 & 0.7964 & 1.2427 & 0.5707 \\
CUS_DEP_TO_TOT_ASSETS & 0.4200 & 0.2089 & 0.8000 & 0.0312 & 0.4385 & 0.2340 & 0.4707 & 0.0839 & 0.4021 & 0.0565
\end{tabular}

\begin{tabular}{lccccccccc} 
& \multicolumn{2}{c}{} & \multicolumn{3}{c}{ United } \\
& \multicolumn{2}{c}{ Sweden } & \multicolumn{2}{c}{ Switzerland } & \multicolumn{2}{c}{ Kingdom } & Total \\
\cline { 2 - 8 } & Mean & SD & Mean & SD & Mean & SD & Mean & \\
\hline INTERBANK_RATIO & 0.1295 & 0.0458 & 0.0902 & 0.1349 & 0.0658 & 0.0409 & 0.133 & 0.1306 \\
DEBT_TO_GDP_RATIO & 0.0038 & 0.0001 & 0.0025 & 0.0002 & 0.0069 & 0.0018 & 0.0059 & 0.0032 \\
LIQUID_ASSETS_RATIO & 0.4860 & 0.1802 & 0.8232 & 1.1353 & 0.4972 & 0.2753 & 0.3800 & 0.5111 \\
CORE_FUNDING_RATIO & 0.3441 & 0.0596 & 0.5338 & 0.2571 & 0.4954 & 0.2384 & 0.5496 & 0.2309 \\
MARKET_TO_BOOK_RATIO & 2.2387 & 2.2738 & 1.6343 & 1.2738 & 1.3589 & 1.0619 & 1.1859 & 1.0129 \\
CUS_DEP_TO_TOT_ASSETS & 0.3111 & 0.0574 & 0.5201 & 0.2213 & 0.4507 & 0.2192 & 0.4964 & 0.2064 \\
\hline
\end{tabular}




\section{TABLE 3}

\section{Market Reaction to Announcements Concerning Bank Liquidity Regulation}

Table 3 presents event study evidence for all seven BCBS announcements about the effect of bank liquidity regulation for a sample of banks from the EU and Switzerland. We present CARs (equal-weighted, EW, and market-weighted, MW) and CMARs (both EW and MW). Panel A uses the MSCI World as a proxy for the market portfolio and Panel B uses the MSCI Europe as a proxy for the market portfolio. The CARs and CMARs are estimated according to equations (1)-(4). BS P-value is the $p$-value for the average CAR and CMAR calculated according to 800 bootstrap simulations for the period Feb. 1, 2008-Feb. 28, 2013. For each simulation, we estimate the average CAR and CMAR according to equations (1)-(4) for seven (or four, for the liquidity-only events $1,2,3$, and 7) randomly selected trading days. To consider only non-events trading days, we exclude days which fall in the 3-day window for the seven events. We randomly choose seven non-overlapping placebo events for the period Feb. 1, 2008-Feb. 28, 2013. This step is repeated 800 times. We compute the sum of the CAR and CMAR over all seven events for each of the 800 samples of placebo events. These steps ensure that the simulated data represent the distribution of CAR and CMAR under the null hypothesis, because they have been estimated for non-events trading days (for which, therefore, announcements related to bank liquidity regulation did not occur). The $p$-values are computed on the basis of the number of cases for which the CAR or CMAR is larger or smaller than the estimated value (2-tail tests). * **, and *** indicate significance at the $10 \%$, $5 \%$, and $1 \%$ levels, respectively. 
TABLE 3 (continued)

Panel A. Market Portfolio Proxy: MSCI World

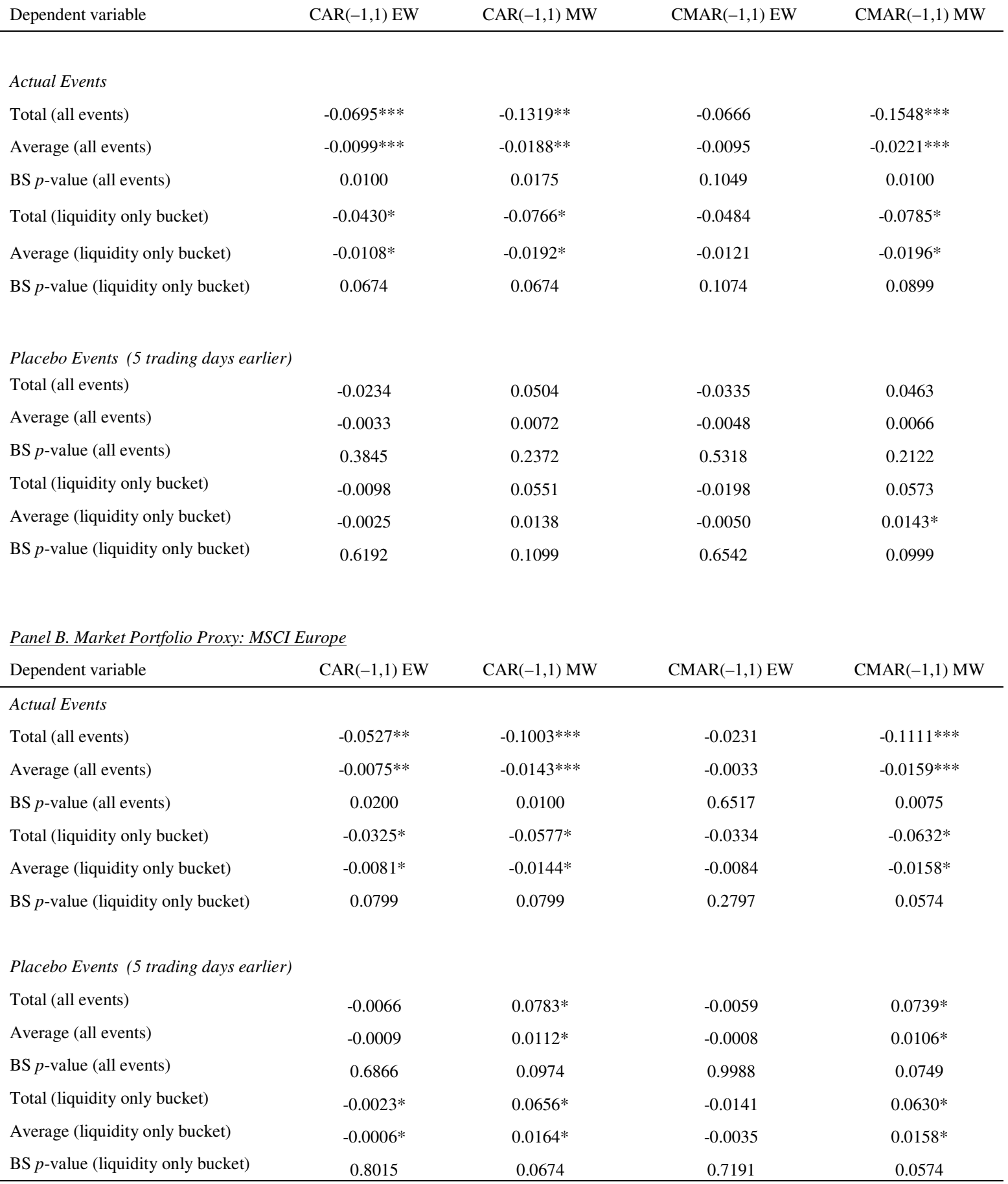


TABLE 4

\section{Determinants of CARs and CMARs}

Table 4 presents tests that explain the effect of the bank-specific variables

CORE_FUNDING_RATIO,LIQUID_ASSETS_RATIO, MARKET_TO_BOOK_RATIO, CUS_DEP_TO_TOT_ASSETS, and the country-specific variables average INTERBANK_RATIO,DEBT_TO_GDP_RATIO, EUROZONE membership, location in GIIPS, and LIQUIDITY_REGULATION on the cross-sectional variation of CARs and CMARs. Panel A uses the MSCI World as a proxy for the market portfolio and Panel B uses the MSCI Europe as a proxy for the market portfolio. The CARs and CMARs are estimated according to equations (1)-(4). We use random effects regressions with robust standard errors clustered at the country level.CORE_FUNDING_RATIO_DUMMY is a dummy that takes the value 1 if the CORE_FUNDING_RATIO is above the 75th percentile, and 0 otherwise. All bank-level variables, CARs and CMARs are winsorized at the 1st and 99th percentile. Constant included but not reported. $t$-statistics in parentheses. *, **, and *** indicate significance at the $10 \%, 5 \%$, and $1 \%$ levels, respectively. 
TABLE 4 (continued)

Panel A. Market Portfolio Proxy. MSCI World

\begin{tabular}{|c|c|c|c|c|}
\hline Dependent Variable & $\operatorname{CAR}(-1,1)$ & $\operatorname{CMAR}(-1,1)$ & $\operatorname{CAR}(-1,1)$ & $\operatorname{CMAR}(-1,1)$ \\
\hline CORE_FUNDING_RATIO & $\begin{array}{c}-0.059 * * * \\
(-3.319)\end{array}$ & $\begin{array}{c}-0.052 * * \\
(-2.394)\end{array}$ & & \\
\hline LIQUID_ASSETS_RATIO & $\begin{array}{c}0.012 * * * \\
(4.268)\end{array}$ & $\begin{array}{c}0.011 * * * \\
(3.494)\end{array}$ & $\begin{array}{c}0.015^{* * * *} \\
(3.815)\end{array}$ & $\begin{array}{c}0.014 * * * \\
(3.694)\end{array}$ \\
\hline CORE_FUNDING_RATIO_DUMMY & & & $\begin{array}{c}0.006 \\
(0.889)\end{array}$ & $\begin{array}{l}0.006 \\
(0.743)\end{array}$ \\
\hline $\begin{array}{l}\text { CORE_FUNDING_RATIO } \times \\
\text { LIQUID_ASSETS_RATIO }\end{array}$ & & & $-0.025^{* * *}$ & $-0.029 * * *$ \\
\hline CUS_DEP_TO_TOT_ASSETS & $\begin{array}{c}0.091 * * * \\
(3.961)\end{array}$ & $\begin{array}{c}0.092 * * * \\
(3.440)\end{array}$ & $\begin{array}{c}(-2.703) \\
0.031 * * * \\
(2.592)\end{array}$ & $\begin{array}{c}(-2.589) \\
0.042 * * * \\
(2.660)\end{array}$ \\
\hline MARKET_TO_BOOK_RATIO & $\begin{array}{c}0.000 \\
(0.192)\end{array}$ & $\begin{array}{c}0.000 \\
(0.049)\end{array}$ & $\begin{array}{c}0.001 \\
(0.684)\end{array}$ & $\begin{array}{l}0.001 \\
(0.417)\end{array}$ \\
\hline INTERBANK_RATIO & $\begin{array}{c}0.082 * * * \\
(2.682)\end{array}$ & $\begin{array}{c}0.075 * * \\
(2.374)\end{array}$ & $\begin{array}{c}0.069 * * \\
(2.318)\end{array}$ & $\begin{array}{c}0.063 * * \\
(1.976)\end{array}$ \\
\hline DEBT_TO_GDP_RATIO & $\begin{array}{c}0.003 \\
(0.536)\end{array}$ & $\begin{array}{c}0.002 \\
(0.250)\end{array}$ & $\begin{array}{c}0.001 \\
(0.246)\end{array}$ & $\begin{array}{c}0.000 \\
(0.017)\end{array}$ \\
\hline EUROZONE & $\begin{array}{l}-0.004^{*} \\
(-1.953)\end{array}$ & $\begin{array}{c}-0.003 \\
(-1.272)\end{array}$ & $\begin{array}{c}-0.005 * * \\
(-2.397)\end{array}$ & $\begin{array}{l}-0.004^{*} \\
(-1.722)\end{array}$ \\
\hline GIIPS & $\begin{array}{c}-0.009 \\
(-1.549)\end{array}$ & $\begin{array}{c}-0.009 \\
(-1.376)\end{array}$ & $\begin{array}{l}-0.010^{*} \\
(-1.691)\end{array}$ & $\begin{array}{c}-0.008 \\
(-1.439)\end{array}$ \\
\hline LIQUIDITY_REGULATION & $\begin{array}{l}-0.000 \\
(-0.019)\end{array}$ & $\begin{array}{c}-0.001 \\
(-0.375)\end{array}$ & $\begin{array}{l}0.003 \\
(1.367)\end{array}$ & $\begin{array}{c}0.002 \\
(0.576)\end{array}$ \\
\hline$R^{2}$ & 0.0321 & 0.0308 & 0.0427 & 0.0437 \\
\hline No. of obs. & 754 & 754 & 754 & 754 \\
\hline No. of banks & 121 & 121 & 121 & 121 \\
\hline
\end{tabular}

Panel B. Market Portfolio Proxy. MSCI Europe

\begin{tabular}{|c|c|c|c|c|}
\hline Dependent Variable & $\operatorname{CAR}(-1,1)$ & $\operatorname{CMAR}(-1,1)$ & $\operatorname{CAR}(-1,1)$ & $\operatorname{CMAR}(-1,1)$ \\
\hline CORE_FUNDING_RATIO & $\begin{array}{c}-0.064 * * * \\
(-3.712)\end{array}$ & $\begin{array}{c}-0.060 * * \\
(-2.523)\end{array}$ & & \\
\hline LIQUID_ASSETS_RATIO & $\begin{array}{c}0.013^{* * * *} \\
(4.136)\end{array}$ & $\begin{array}{c}0.012^{* * * *} \\
(3.631)\end{array}$ & $\begin{array}{c}0.015^{* * * *} \\
(3.555)\end{array}$ & $\begin{array}{c}0.015 * * * \\
(3.574)\end{array}$ \\
\hline CORE_FUNDING_RATIO_DUMMY & & & $\begin{array}{c}0.005 \\
(0.788)\end{array}$ & $\begin{array}{c}0.005 \\
(0.536)\end{array}$ \\
\hline $\begin{array}{l}\text { CORE_FUNDING_RATIO } \times \\
\text { LIQUID_ASSETS_RATIO }\end{array}$ & & & $-0.024 * * *$ & $-0.025^{* *}$ \\
\hline & & & $(-2.578)$ & $(-2.207)$ \\
\hline CUS_DEP_TO_TOT_ASSETS & $\begin{array}{c}0.092 * * * \\
(4.063)\end{array}$ & $\begin{array}{c}0.102 * * * \\
(3.450)\end{array}$ & $\begin{array}{l}0.028^{* * *} \\
(2.393)\end{array}$ & $\begin{array}{c}0.043 * * * \\
(2.584)\end{array}$ \\
\hline MARKET_TO_BOOK_RATIO & $\begin{array}{c}0.001 \\
(0.365)\end{array}$ & $\begin{array}{l}-0.001 \\
(-0.258)\end{array}$ & $\begin{array}{c}0.002 \\
(0.876)\end{array}$ & $\begin{array}{c}0.000 \\
(0.101)\end{array}$ \\
\hline INTERBANK_RATIO & $\begin{array}{c}0.090 * * * \\
(3.022)\end{array}$ & $\begin{array}{c}0.091 * * \\
(2.524)\end{array}$ & $\begin{array}{c}0.076 * * * \\
(2.614)\end{array}$ & $\begin{array}{c}0.078^{* *} \\
(2.125)\end{array}$ \\
\hline DEBT_TO_GDP_RATIO & $\begin{array}{c}0.004 \\
(0.700)\end{array}$ & $\begin{array}{c}0.003 \\
(0.369)\end{array}$ & $\begin{array}{c}0.002 \\
(0.352)\end{array}$ & $\begin{array}{c}0.001 \\
(0.089)\end{array}$ \\
\hline EUROZONE & $\begin{array}{c}-0.006^{* *} \\
(-2.115)\end{array}$ & $\begin{array}{c}-0.004 \\
(-1.561)\end{array}$ & $\begin{array}{c}-0.007 * * \\
(-2.429)\end{array}$ & $\begin{array}{c}-0.005 * * \\
(-1.989)\end{array}$ \\
\hline GIIPS & $\begin{array}{l}-0.010 \\
(-1.580)\end{array}$ & $\begin{array}{l}-0.012 \\
(-1.627)\end{array}$ & $\begin{array}{l}-0.010^{*} \\
(-1.694)\end{array}$ & $\begin{array}{l}-0.012 * \\
(-1.694)\end{array}$ \\
\hline LIQUIDITY_REGULATION & $\begin{array}{l}-0.001 \\
(-0.344)\end{array}$ & $\begin{array}{l}-0.001 \\
(-0.314)\end{array}$ & $\begin{array}{c}0.002 \\
(1.101)\end{array}$ & $\begin{array}{c}0.002 \\
(0.775)\end{array}$ \\
\hline$R^{2}$ & 0.0308 & 0.0284 & 0.0428 & 0.0419 \\
\hline No. of ob. & 754 & 754 & 754 & 754 \\
\hline No. of banks & 121 & 121 & 121 & 121 \\
\hline
\end{tabular}


TABLE 5

Determinants of CARs and CMARs for the Liquidity only bucket

Table 5 presents tests to explain the effect of bank-specific variables

CORE_FUNDING_RATIO, LIQUID_ASSETS_RATIO, MARKET_TO_BOOK_RATIO,

CUS_DEP_TO_TOT_ASSETS, and country-specific variables average

INTERBANK_RATIO, DEBT_TO_GDP_RATIO, EUROZONE membership, location in

GIIPS, and LIQUIDITY_REGULATION on the cross-sectional variation of CARs and

CMARs. These tests are identical to those shown in Table 4, except for the fact that we focus

on the Liquidity only bucket. Panel A uses the MSCI World as a proxy for the market

portfolio and Panel B uses the MSCI Europe as a proxy for the market portfolio. The CARs

and CMARs are estimated according to equations (1)-(4). We use random effects regressions

with robust standard errors clustered at the country level. All bank-level variables, CARs and

CMARs are winsorized at the 1 st and 99 th percentile. $t$-statistics in parentheses. *, ${ }^{* *}$, and

*** indicate significance at the $10 \%, 5 \%$, and $1 \%$ levels, respectively. 
TABLE 5 (continued)

Panel A. Market Portfolio Proxy: MSCI World

Dependent Variable

CORE_FUNDING_RATIO

LIQUID_ASSETS_RATIO

MARKET_TO_BOOK_RATIO

CUS_DEP_TO_TOT_ASSETS

INTERBANK_RATIO

DEBT_TO_GDP_RATIO

EUROZONE

GIIPS

LIQUIDITY_REGULATION

Constant

$R^{2}$

No. of obs.

No. of banks

Panel B. Market Portfolio Proxy: MSCI Europe

Dependent Variable

CORE_FUNDING_RATIO

LIQUID_ASSETS_RATIO

MARKET_TO_BOOK_RATIO

CUS_DEP_TO_TOT_ASSETS

INTERBANK_RATIO

DEBT_TO_GDP_RATIO

EUROZONE

GIIPS

LIQUIDITY_REGULATION

Constant

$R^{2}$

No. of obs.

No. of banks
CAR $(-1,1)$

$\operatorname{CMAR}(-1,1)$

$\begin{array}{cc}-0.080^{* *} & -0.086^{* *} \\ (-2.506) & (-2.237) \\ 0.010^{* * *} & 0.009 * * * \\ (3.008) & (2.584) \\ -0.001 & -0.000 \\ (-0.628) & (-0.073) \\ 0.103 * * * & 0.110^{* *} \\ (2.632) & (2.336) \\ 0.046 & 0.059 \\ (1.243) & (1.447) \\ -0.004 & -0.005 \\ (-0.418) & (-0.539) \\ -0.006 * * & -0.005 \\ (-2.114) & (-1.524) \\ 0.005 & 0.005 \\ (0.911) & (0.807) \\ -0.008 * * * & -0.008 * * * \\ (-4.038) & (-3.497) \\ -0.018 * * & -0.017 * \\ (-2.229) & (-1.859) \\ & \\ 0.0250 & 0.0281 \\ 401 & 401 \\ 117 & 117\end{array}$

CAR $(-1,1)$

$\operatorname{CMAR}(-1,1)$

$\begin{array}{cc}-0.090^{* * *} & -0.086^{* * *} \\ (-2.886) & (-2.236) \\ 0.011^{* * *} & 0.009^{* * * *} \\ (3.031) & (2.578) \\ -0.001 & -0.000 \\ (-0.401) & (-0.063) \\ 0.110^{* * *} & 0.110^{* *} \\ (2.886) & (2.335) \\ 0.056 & 0.059 \\ (1.475) & (1.449) \\ -0.010 * * * & -0.008 * * \\ (-4.786) & (-3.496) \\ -0.006 * * & -0.005 \\ (-2.139) & (-1.523) \\ 0.007 & 0.005 \\ (1.035) & (0.807) \\ -0.007 & -0.005 \\ (-0.719) & (-0.539) \\ -0.013 & -0.017 * \\ (-1.467) & (-1.862) \\ & \\ 0.0319 & 0.0281 \\ 401 & 401 \\ 117 & 117\end{array}$




\section{FIGURE 1}

\section{Core and Periphery Countries in Europe}

Figure 1 plots a map with all countries in our sample. Greece, Ireland, Italy, Portugal, and Spain are considered periphery countries in the public debate about the Eurozone crisis.

These countries experienced sovereign debt problems; they are highlighted in dark grey.

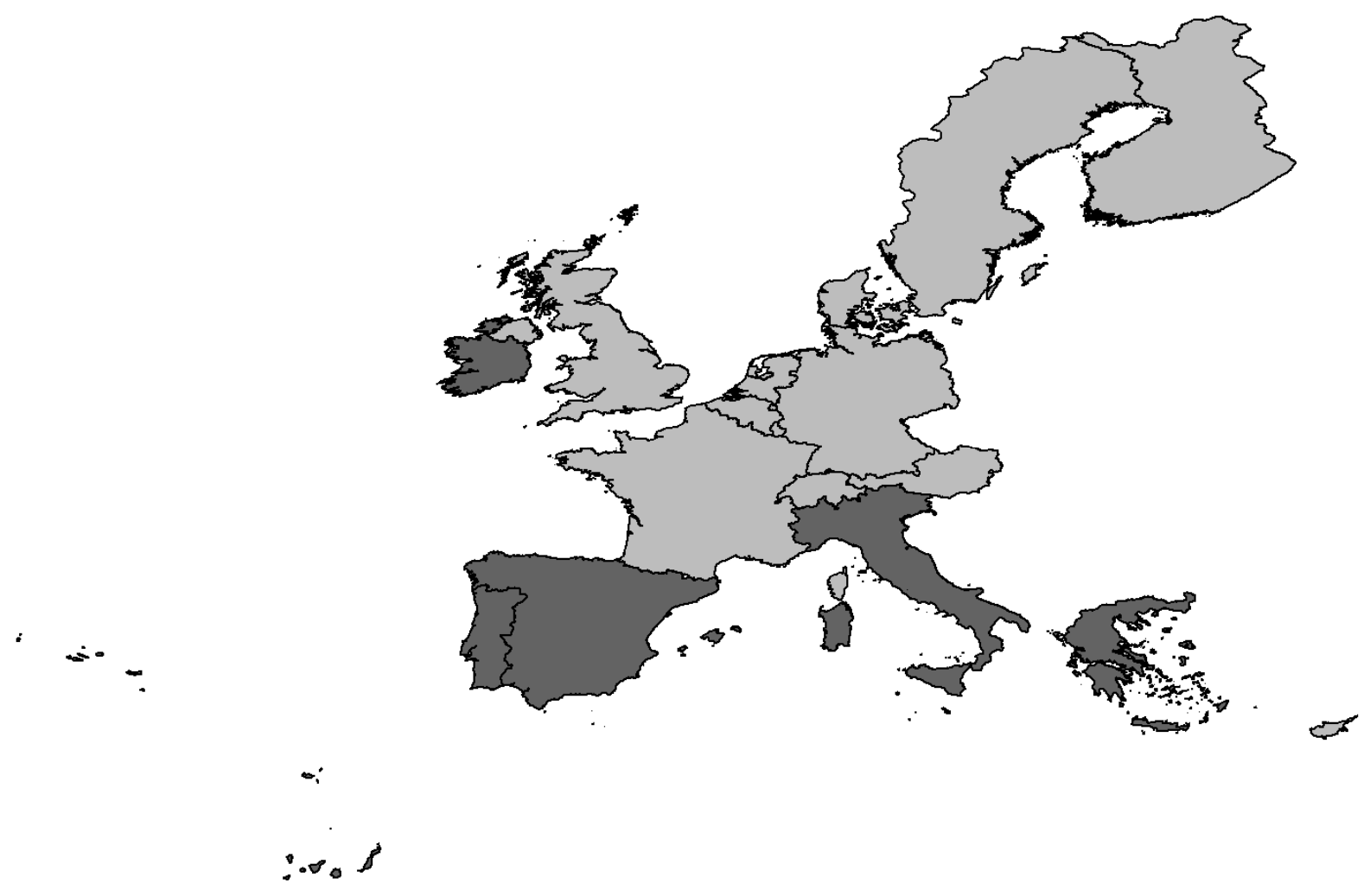




\section{FIGURE 2}

\section{Non-Eurozone Countries}

Figure 2 highlights the countries that are not members of the Eurozone (Sweden, Denmark, Switzerland, and the United Kingdom). These countries are highlighted in dark grey.
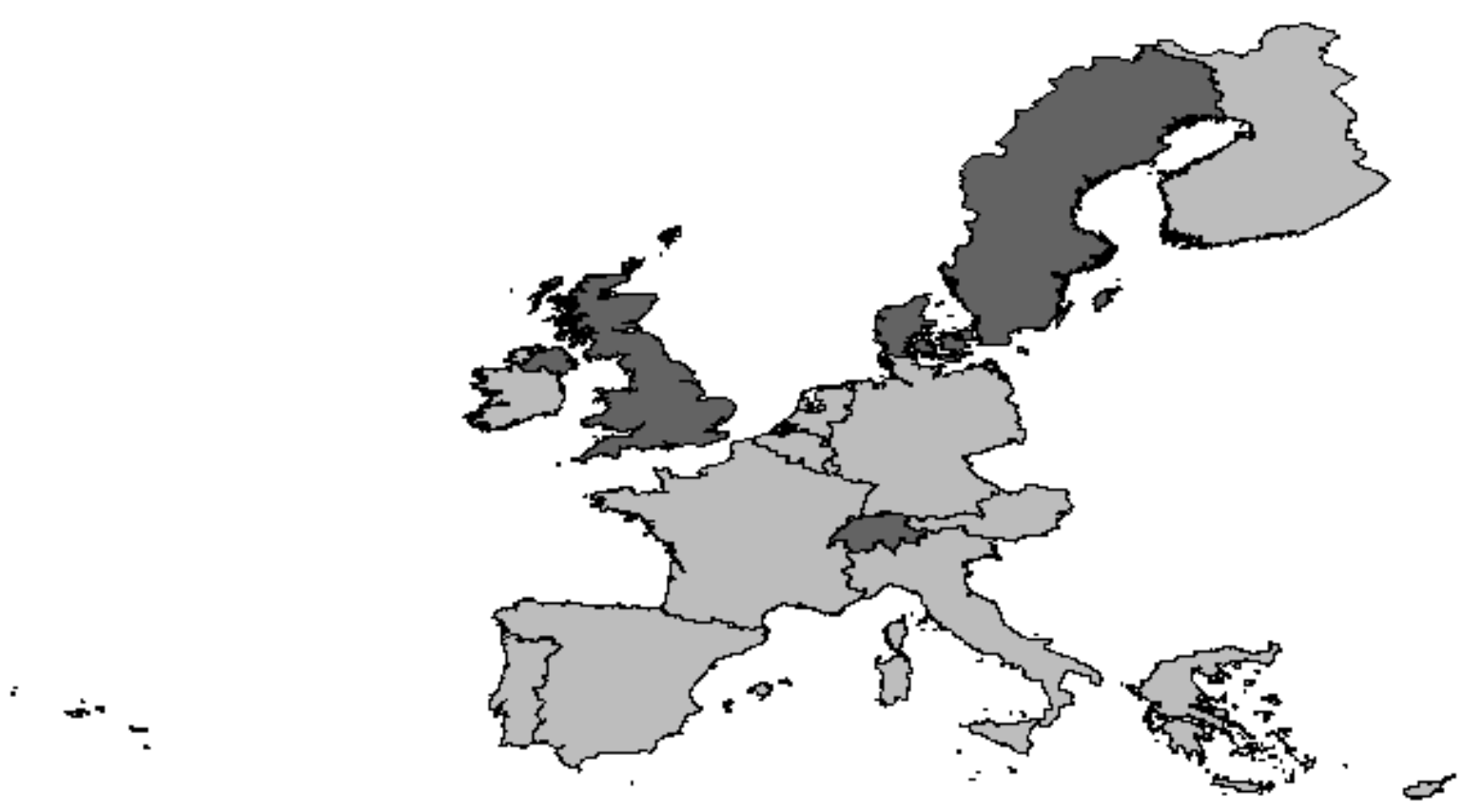

$$
\therefore+\sigma_{0}
$$




\section{FIGURE 3}

\section{Countries in Europe with Pre-Existing Domestic Liquidity Regulation}

Figure 3 shows which countries had pre-existing domestic rules for the regulation of bank liquidity in place. Switzerland, the United Kingdom, Germany, and Denmark had such legislation prior to the announcements of the BCBS in place. These countries are highlighted in dark grey.

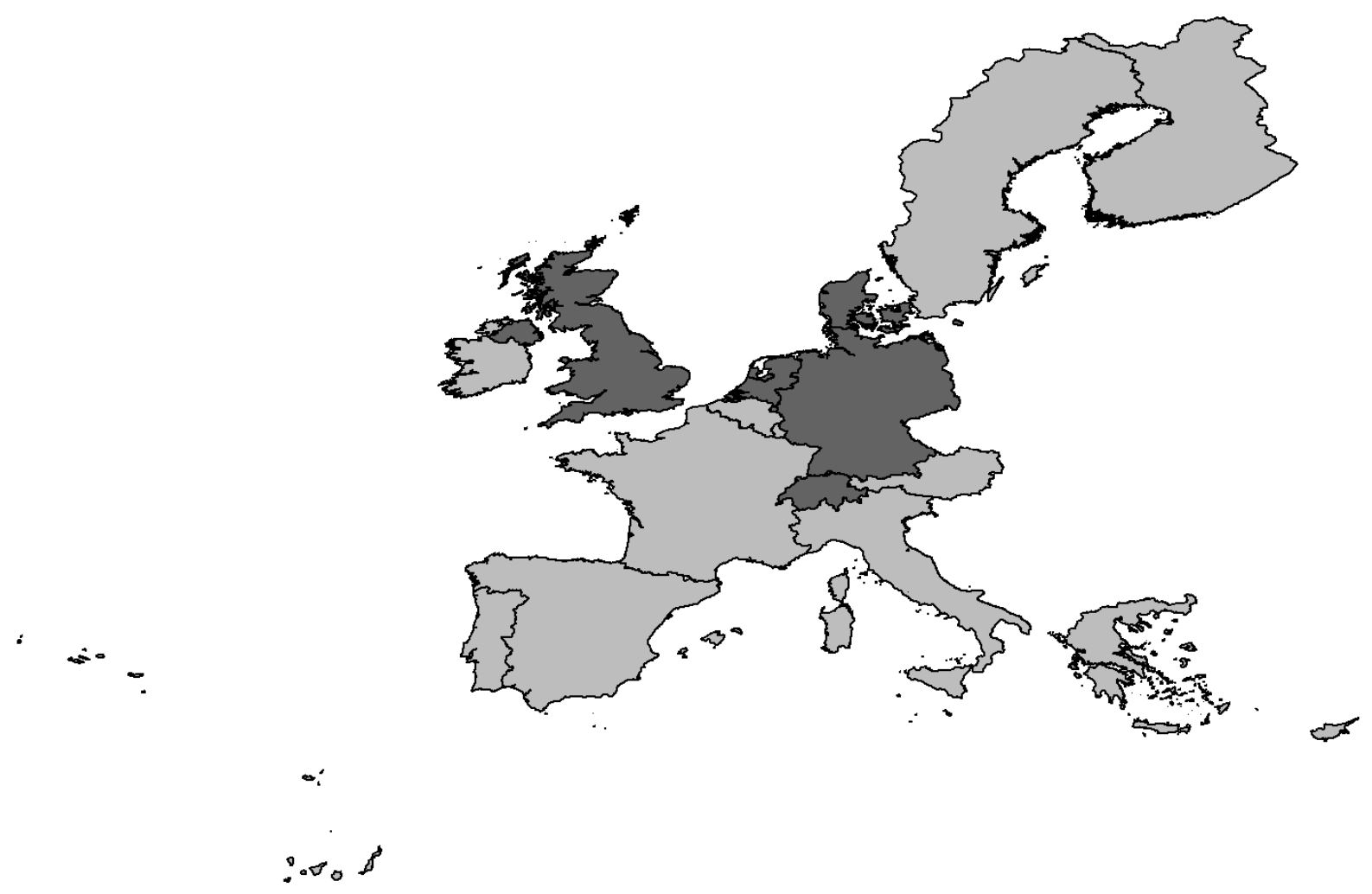




\section{FIGURE 4}

\section{CARs and CMARs around the Event Dates}

Graphs A-D of Figure 4 illustrate the behavior of equal-weighted and market-weighted CARs and CMARs around a 3-day event window centred on the announcement date (represented with a vertical solid bold line). The solid line represents CARs (Graphs A and B) or CMARs (Graphs C and D) estimated using the MSCI World as a proxy for the market portfolio, while the dashed line represents CARs (Graphs A and B) or CMARs (Graphs C and D) estimated using the MSCI Europe as a proxy for the market portfolio. Graphs A and C use a marketweighted portfolio of banks, while Graphs B and D use an equal-weighted portfolio of the bank stocks in our sample. 
FIGURE 4 (continued)

Graph A. Market-Weighted Portfolio CAR(-1,1)

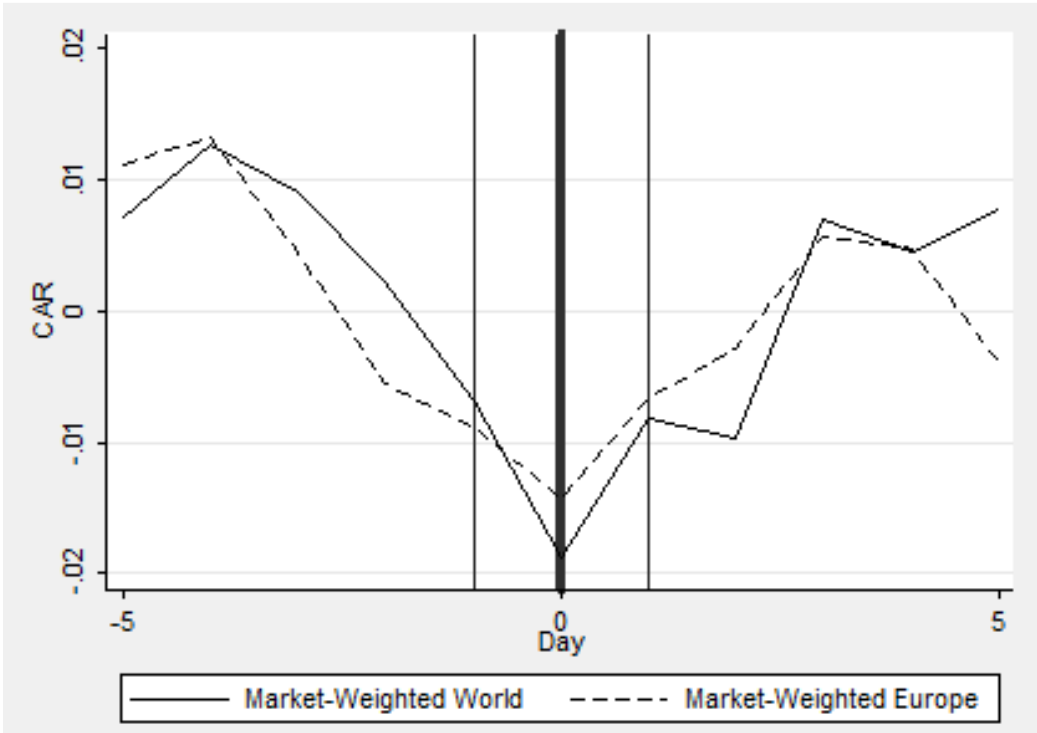

Graph B. Equal-Weighted Portfolio CAR $(-1,1)$

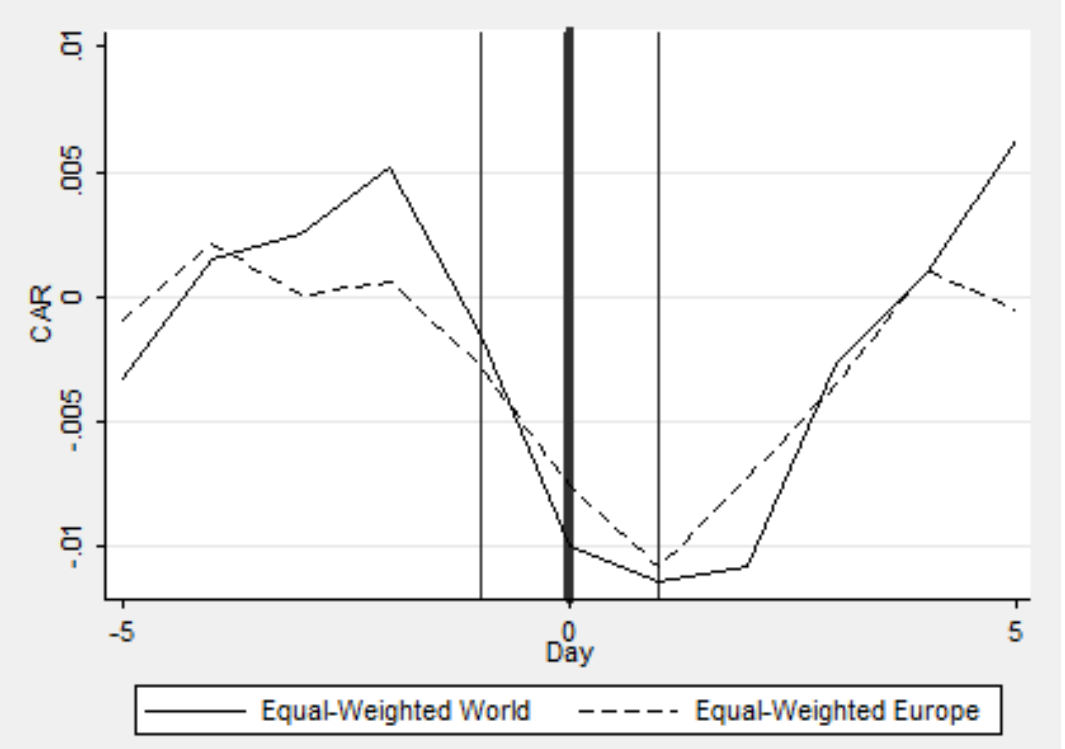


FIGURE 4 (continued)

Graph C. Market-Weighted Portfolio CMAR $(-1,1)$

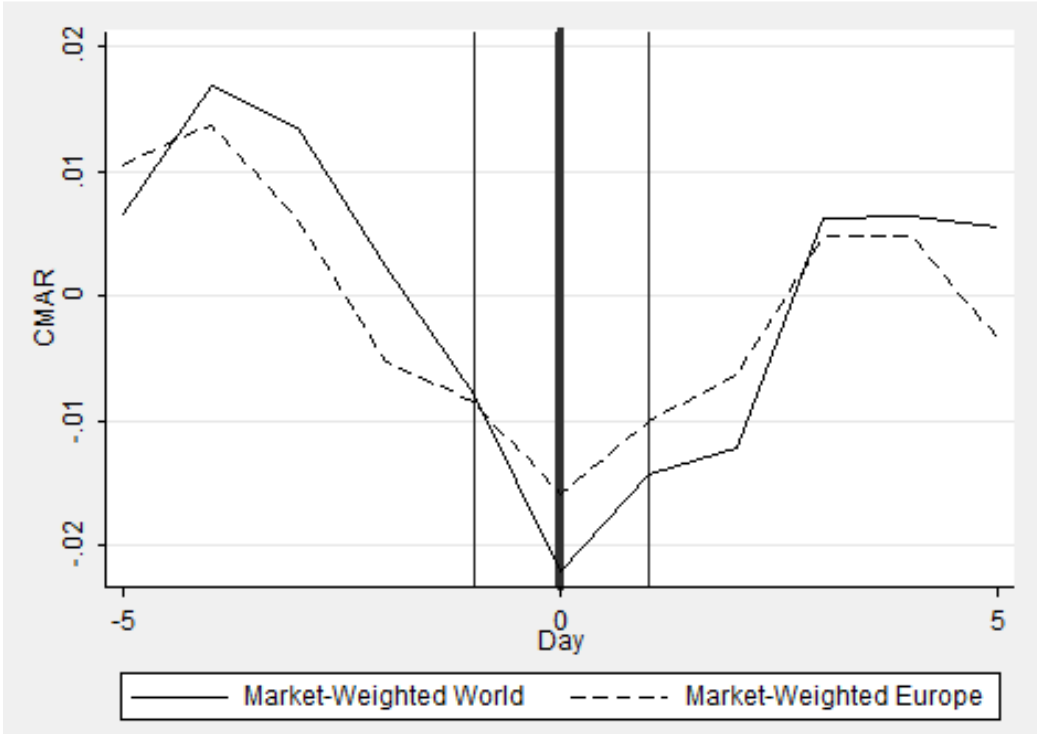

Graph D. Equal-Weighted Portfolio CMAR $(-1,1)$

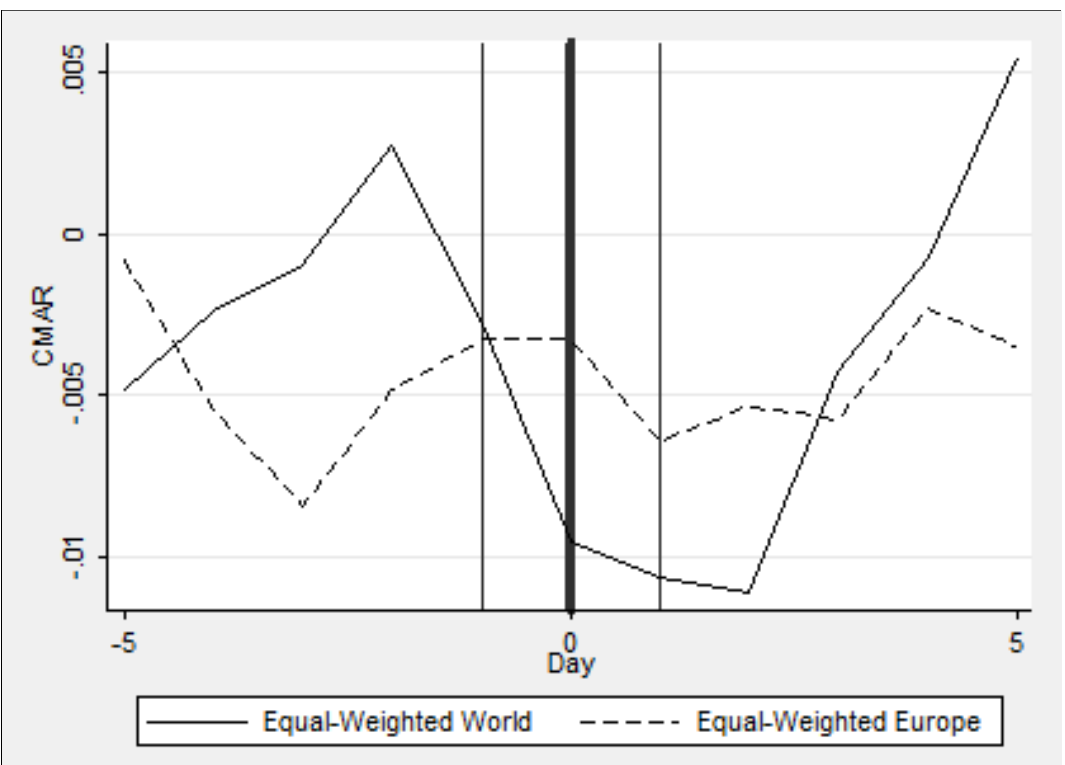

